\title{
CRITIQUE OF RECENT WORK ON THE MORPHOLOGY OF THE VERTEBRATE SKULL, ESPECIALLY IN RELATION TO THE ORIGIN OF MAMMALS
}

\author{
WILLIAM K. GREGORY \\ From the American Museum of Natural History, New York \\ TWENTY-FIVE FIGURES
}

CONTENTS

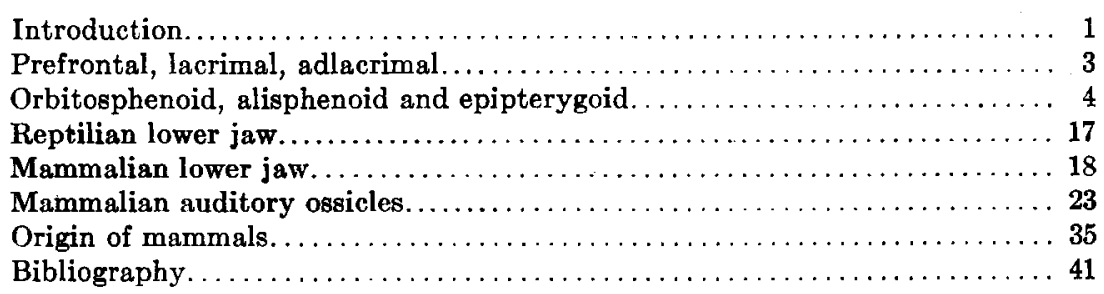

\section{INTRODUCTION}

To observers who have followed the trend of zoological research during recent years it is apparent that zoologists have in great numbers turned away from vertebrate comparative anatomy as a thankless task and have come to regard its labyrinths as leading nowhere. The rise of statistical and experimental research has accompanied a reaction against such speculative conclusions as those of Gegenbaur and Dohrn and it has been said that neither comparative anatomy nor paleontology have told us by what steps organs have been evolved but only how they may have been evolved. It has even been hinted that our theories of phylogeny and morphogeny are too much the product of the unchecked imagination, which seizes gladly upon favorable evidence but fails to seek the unfavorable. 
In this country the falling off in the total output of comparative anatomical research has been especially noticeable, and only a few Americans have continued along the old paths. In the morphology of the vertebrate skull, the special topic of this review, it is only here and there, as at Cornell, Tufts and a few other centers, that organized and continuous research has resulted in such fine contributions as Kingsbury and Reid's on the columella auris in Amphibia ('09) or Thyng's on the squamosal ('06).

In Germany, on the contrary, while statistical and experimental investigations have likewise received an extraordinary impetus, the older fields are not left without enthusiastic workers. There the problems of the vertebrate skull still have a human interest; men still take sides over questions of homology and even get to the point of abusing each other in print.

In certain problems of the vertebrate skull which were opened by Cuvier, Owen, Reichert, Kitchen Parker and other pioneers, the eminent morphologist of Freiburg whose recent studies it is my purpose to review has been a prolific investigator. Thanks in no small degree to Gaupp, this subject is no longer in a state of fixity and stagnation, but at least in Germany, has again become mobile.

The nomenclature of the skull, alas, is also passing through a period of unstable equilibrium. The student soon learns that many of the familiar names for the bony elements of the skull, names which have become almost sancrosanct through the prestige of Owen and Huxley, are now being abandoned by certain authors, transferred to other elements, or sometimes even transposed. Squamosal, prosquamosal and supratemporal; prefrontal, lacrimal, adlacrimal and postnasal; prevomer, vomer and parasphenoid; orbitosphenoid, alisphenoid and epipterygoid; these are examples of names affixed to certain Protean elements, the transformations of which in the different Classes have given rise to synonymy and confusion. 


\section{PREFRONTAL, LACRIMAL, ADLACRIMAL}

The prefrontal of the lizard and other recent reptiles has been shown by Gaupp ('10) to have the same or nearly the same relations with the chondrocranium and with the naso-lacrimal duct as has the lacrimal of mammals. The so-called lacrimal of

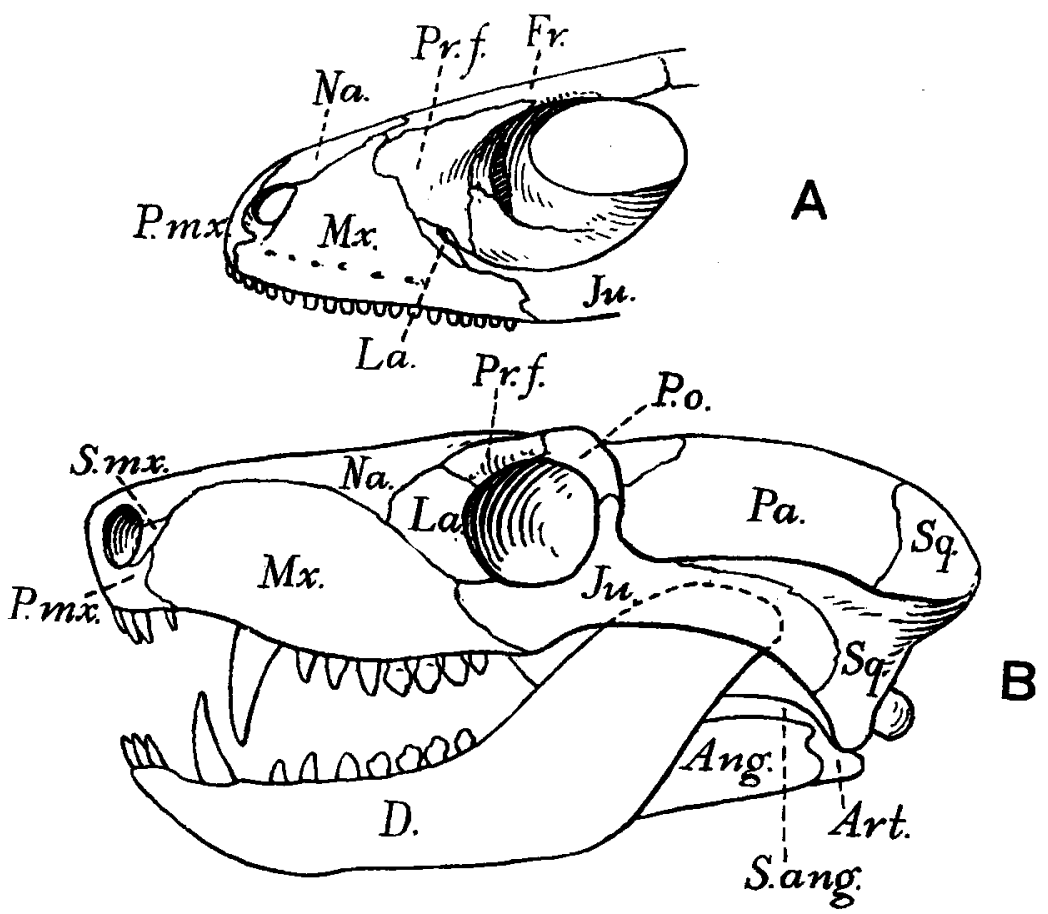

Fig. 14 , The lacrimal region of Lacerta viridis. After Gaupp, 1910, p. 532.

The lacrimal ('adlacrimal') is vestiglal, the prefrontsl has the appearance and position of the mammalian lacrimal.

$B$, Skull of the primitive Cynodont Nythosaurus larvatus. After Broom, (1911, text,-fig. 170, p. 899).

The lacrimal is well developed and has the normal relations of the mammalian lacrimal, the prefrontal is separated by the lacrimal from the jugal; it is in contact with the nasal and lacrimal like the anterosuperior portion of the 'frontal' of mammals.

reptiles (which only in the Crocodilia is pierced by the duct) is widely removed from the chondrocranium and in the lizards is an inconstant element. On these and similar grounds Gaupp concludes, with Kober and Jaekel, that the prefrontal of the 
reptiles is the homologue of the lacrimal of the mammals and that the reptilian prefrontal should therefore in future be called 'lacrimale'1 since the mammalian and especially the human skull is taken for the basis of nomenclature. On the other hand, thinks Gaupp, the so-called lacrimal of reptilians and stegocephalians has disappeared in the mammals and should be called either 'postnasal' (Jaekel) or 'adlacrimal' (Gaupp).

There is, however, one objection to this conclusion: it is founded on a comparison between mammals and recent reptiles and leaves the extinct Theriodontia altogether out of account. The lacrimal (adlacrimal of Gaupp) of Cynognathus, Trirachodon, etc., in Broom's recent figures ('11) is similar to the mammalian lacrimal in appearance and position, while the prefrontal borders the orbit superiorly and has neither the appearance nor the position of the mammalian lacrimal.

In no Cynodont is the lacrimal vestigial, in none is the prefrontal in contact with the jugal as it should be if it were about to transform into the mammalian lacrimal. Nor is there any suggestion that the reptilian prefrontal has fused with the 'lacrimal' to form the true lacrimal of mammals; on the contrary the prefrontal may have fused with the frontal to form the superior border of the orbit.

Since the Theriodonts appear to be in every respect closer to the mammals than the lizards are, ${ }^{2}$ it seems probable that the resemblances between the prefrontal of the lizard and the lacrimal of mammals have resulted from convergent evolution and that it is incorrect to homologize the reptilian prefrontal with the mammalian lacrimal or to transfer the name lacrimal to the prefrontal.

\section{ORBITOSPHENOID, ALISPHENOID AND EPIPTERYGOID}

Another pair of elements of the reptilian skull whose customary name and supposed homology have lately been called in question are the 'alisphenoids.'

Gaupp has shown ('02, '11) that, in the cartilaginous cranium of mammals, the alae temporalis (fig. 2), which are replaced by

I 'Lacrimale' is etymologically correct (Lat. lacrima, a tear).

2 See below. 

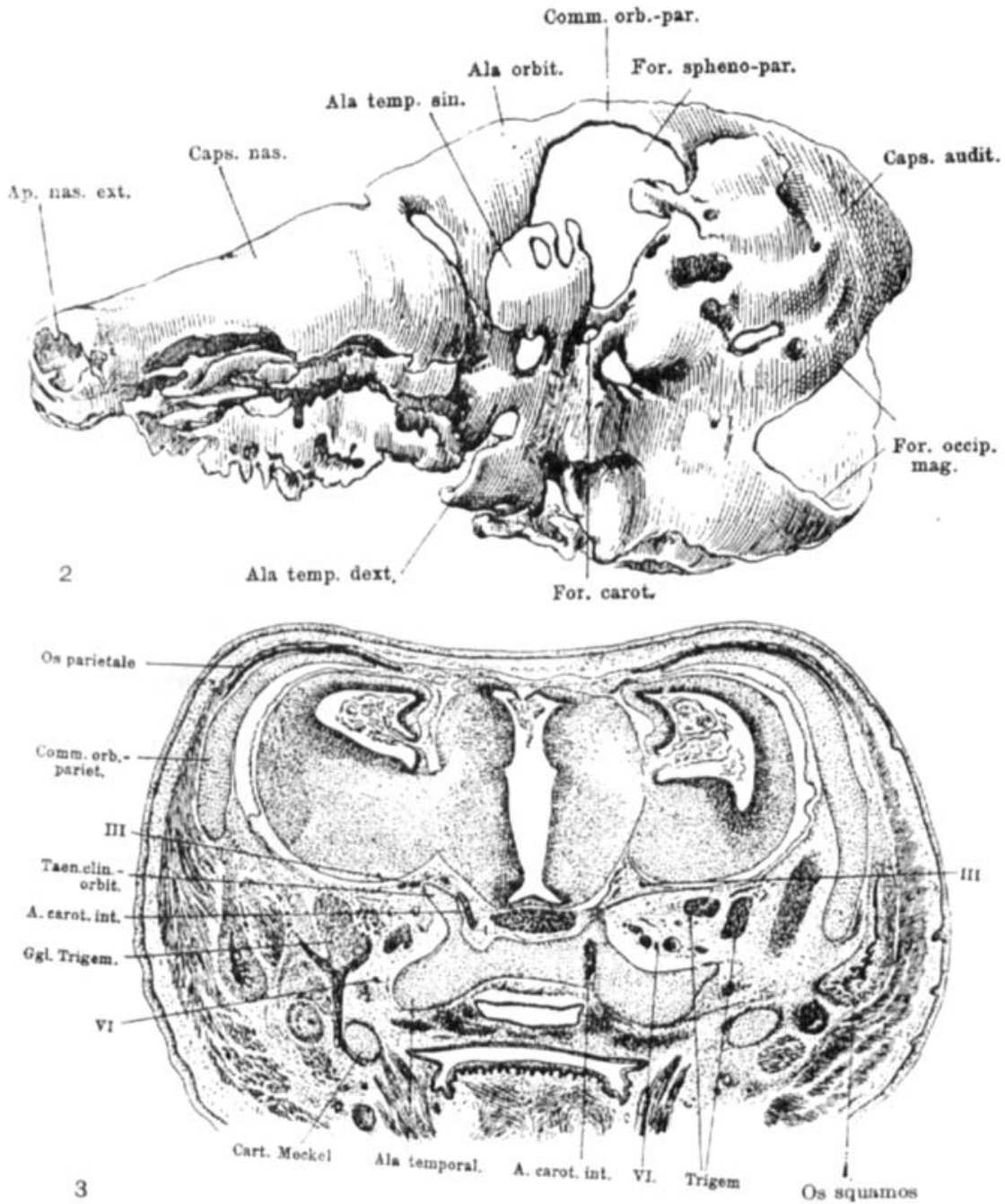

Fig. 2 Model of the chondrocranium of Talpa europaea, from Gaupp (Merkel u. Bonnet's Anat. Hefte, Ixi, 1902, fig. 10, p. 193) after E. Fischer. Seen obliquely from below.

The ala temporalis (cartilage fundament of the alisphenold) lies outside of the primitive brain case. It is connected below with the basisphenold. The als orbitalis (cartilage fundament of the orbitosphenoid) is a part of the primitive brain case; it is posterior to the ethmoid and lateral to the presphenoid.

Fig. 3 Cross section through the sella turcica of a larval Echidna aculeata. From Gaupp (Merkel u. Bonnet's Anat. Héfte., lxi, 1902, fig. 14, p. 201).

The cartlage fundaments (alm temporalis) of the alsphenolds form no part of the primordial brain case but lie below and outside of the Gasserian ganglia (Ggl.trigem.); they are lateral to the carotid canal (A.carot.int.) and to the basisphennid. 
the alisphenoid bones, arise as rods or tracts of cartilage lying outside of and below the Gasserian ganglia and separated by them from the true brain cavity (fig. 3). In the embryonic skull these cartilaginous alae temporalis (fig. 3) spring from either side of the basisphenoid, very much as do the basipterygoid processes in the lizard skull (fig. 4); they also hold similar topographic relations with the carotid arteries. For these and similar reasons Gaupp does not hesitate to homologize the alae tem-

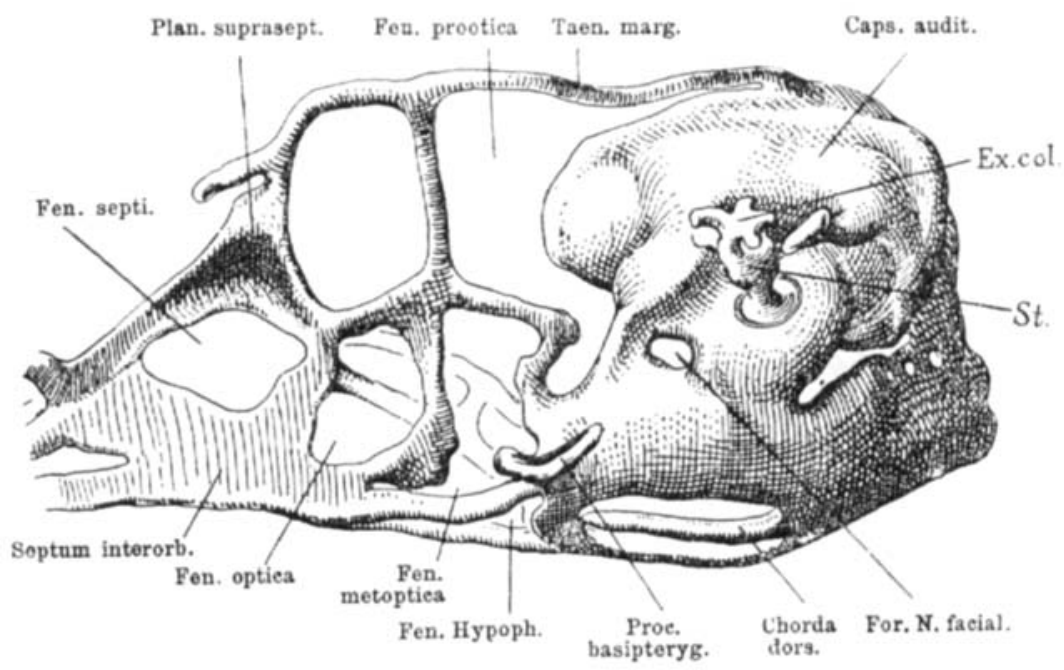

Fig. 4 Chondrocranium of Lacerta agilis. From Gaupp (Merkel u. Bonnet's Anat. Hefte, 1xi, 1902, fig. 5, p. 171).

The basipterygoid process, springing from the basisphenoid, lies outside of the primordial brain case and below the Gasserian ganglion, like the ala temporalis of mammals.

poralis of mammals with the basipterygoid processes of reptiles. These processes he supposes to have become turned upward, so that they embraced the Gasserian ganglia externally; by further upgrowth of the replacing bone they covered the temporal region of the skull. The conclusion is drawn that the mammalian alisphenoids are not represented as such in the reptilian skull, that the pair of bones in the Crocodilia usually called alisphenoids represent some other elements. Accepting these views, Dr. von Huene ('11) applies them in the field of paleontology: "Die 
Bezeichnung Alisphenoid dürfte künftig bei keinem Sauropsiden mehr benützt werden. Der bisher so bezeichnete Knochen ist ident mit den Orbitosphenoid."

Last year the present writer had the privilege of studying the skulls of Tyrannosaurus and other Dinosaurs in the American Museum of Natural History in collaboration with Professor Osborn ('12) and Doctor von Huene, and was inclined to accept the view of the latter that the principal elements in the walls of the reptilian skulls are not alisphenoids but orbitosphenoids. Further study, however, has led to the following considerations: In mammals ${ }^{3}$ the alisphenoids are lateral to the basisphenoid and pituitary fossa, they connect posteriorly with the proötics and superiorly with the parietals, they are pierced posteriorly by nerve V3, and they lie outside of the Gasserian ganglia and behind the sphenorbital fissure (for nerves III, IV, VI); on the lower surface of the skull they are postero-external to the pterygoids and laterally embrace the basisphenoid; they are also chiefly external to the foramina for the internal carotids.

In Cynodonts (fig. 6) there are a pair of elements showing strong resemblances with the mammalian alisphenoids and so named by Broom. In the internal view of the Cynodont skull as figured by Broom ('11), it is seen that these alisphenoids are anterior to the proötics, lateral to the basisphenoid and pituitary fossa, inferior to the parietals. They also lie in front of the foramen proöticum (for nerves V2, V3); to judge from the relations of the small process running from the proötic upward, inward and forward, it seems probable that the supposed alisphenoids also lay outside the Gasserian ganglia; their anterior border looks much like the posterior boundary of the sphenoidal fissure (foramen lacerum anterius), hence they were probably posterior to the exit of nerves II, III, V1, VI, like the alisphenoids of mammals. On the lower surface of the skull the bones called alisphenoid were postero-external to the pterygoids and embraced the basisphenoids laterally just in front of two openings which Broom identifies as "probably for the carotids." Thus the evi-

\footnotetext{
3 See the figures of the skull in embryo marsupials, edentates, insectivores, etc., as figured by Broom, Parker and others (especially Parker, 1885).
} 

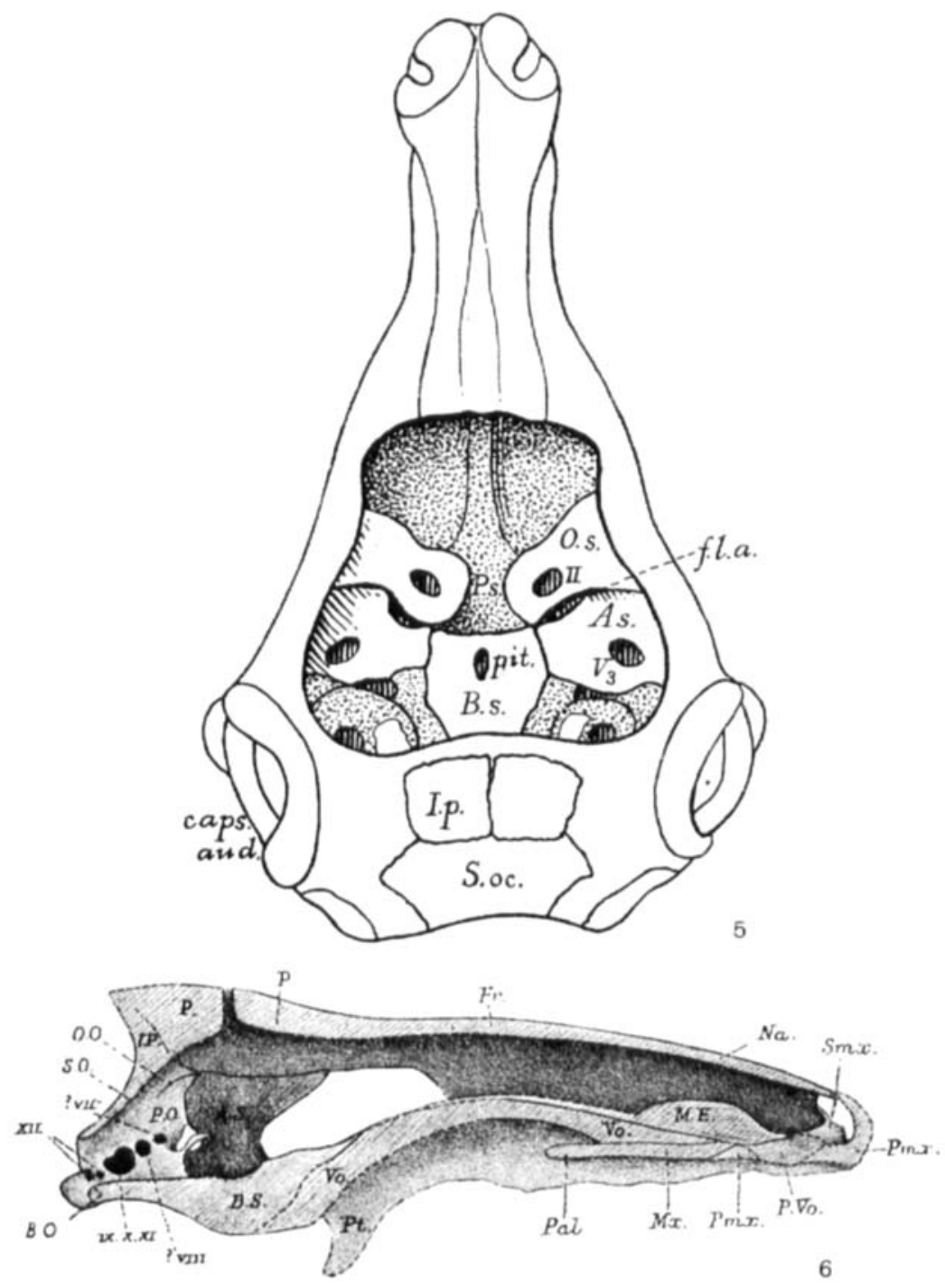

Fig. 5 Brain case of young Erinaceus europaeus. After Parker (1885, p. 19, fig. 4) Seen from above.

The orbitosphenoid is posterior to the ethmold, lateral to the presphenold, anterior to the sphenorbital fissure, (f.l.a.), lateral to the basisphenold and pltuitary fossa, snterlor to the prootlc and chiefly anterior to the foramen ovale $\left(V_{8}\right)$.

Fig. 6 Median section of skull of the Cynodont Diademodon. From Broom (P.Z.S., Dec., 1911, pl. xlvi, fig. 9)

The al lsphenold (A.S.) has the same topographic relations as the alisphenold of mammals. It also appears to be homologous with the alisphenold of Crocodiles and Dinosaurs. The opening in front of the prootic is believed to be the foramen prooticum (for $V_{2}, V_{3}$ ). The amall spicule of bone that divides this opening is thought by Broom to have been medial to the Gasserian ganglion. 
dence for homology with the mammalian alisphenoids is very strong.

Likewise in crocodiles (fig. 7) and Dinosaurs (figs. 8-10) the bones usually called alisphenoids, but called by von Huene 'orbi-

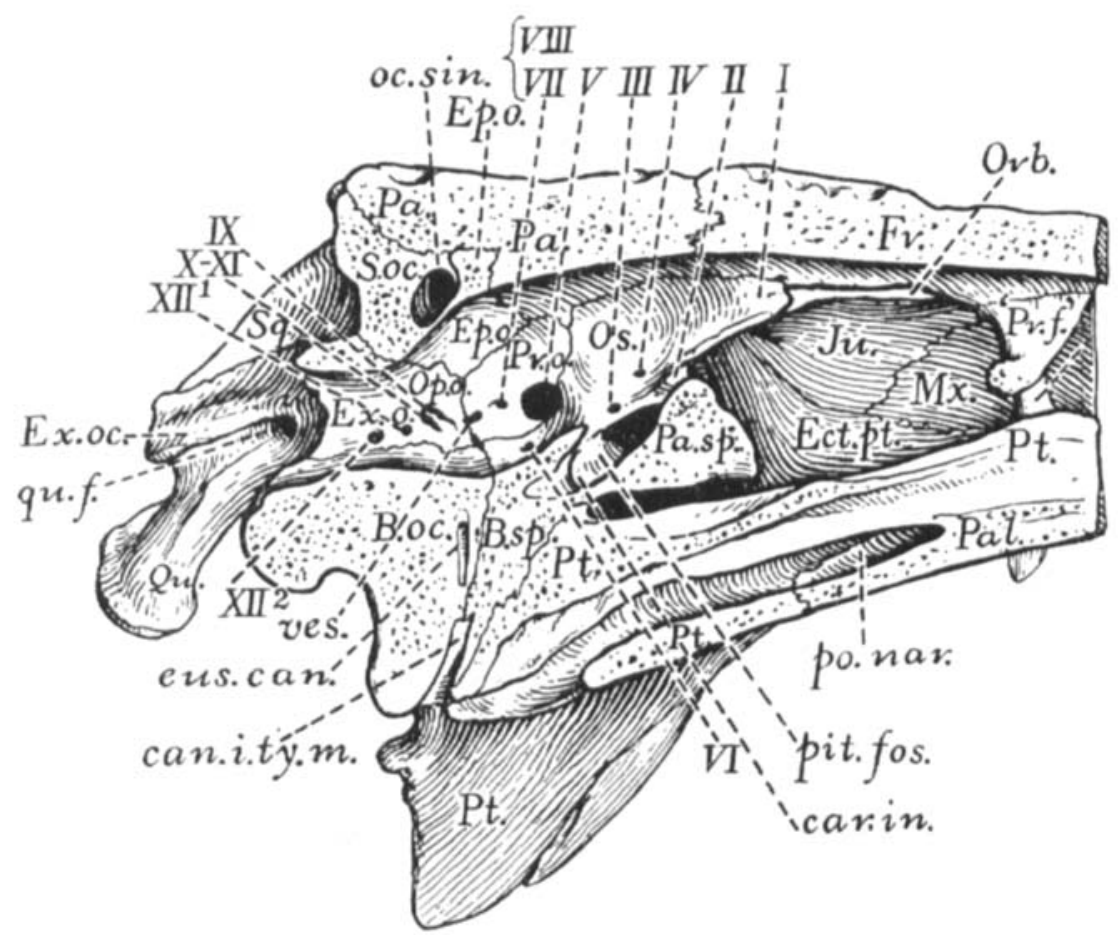

Fig. 7 Median section of the Crocodile skull.

Foramina identified with the kind assistance of Dr. F. von Huene.

The alisphenold (marked O.s.) aggrees with the mammalian and Cynodont alisphenoid in being anterior to the prootic and foramen prooticum (V), lateral to the basisphenoid and pituitary fossa, inferior to the parietal, and chiefly posterior to the foraming for nerves II, III, IV.

Pa. sp., presphenoid (preformed in cartilage).

tosphenoid's' are anterior to the proötics, lateral to the basisphenoid and pituitary fossa, inferior to the parietals and notched or pierced posteriorly by the foramen for nerve V3, they are also chiefly posterior to the exits of nerves II, III, and IV. In the inferior view of the skull the alisphenoids embrace the basi- 
sphenoids, are external to the carotid canals and posterior to the pterygoids.

These comparisons, summarized in the following table, offer strong evidence for the view that the bones usually called alisphenoids in the Dinosaurs and crocodiles are rightly so named.

If, however, the large temporal wing-bones of the braincase in crocodiles and Dinosaurs are alisphenoids where are the true orbitosphenoids? In the crocodile Parker ('83) sought the orbitosphenoids in the persistently cartilaginous lateral wings of the chondrocranium, lying above the presphenoid, behind the ethmoids, below the frontals and in front of the foramina for the optic nerves. These topographic relations are exactly similar to those of the orbitosphenoids of mammals, the chief difference being that in mammals, the orbitosphenoids are osseous. In the Cynodonts the region in front of the alisphenoids remained unossified (Broom).

TABLE 1

Topographic resemblances between the 'alisphenoids' of crocodiles, dinosaurs, cynodonts and mammals

\begin{tabular}{|c|c|c|c|c|}
\hline & $\begin{array}{l}\text { ALIBPHE- } \\
\text { NODB OF } \\
\text { MAMMALA }\end{array}$ & $\begin{array}{c}\text { ALIBPHE- } \\
\text { NOIDD OF } \\
\text { CYNODONTE }\end{array}$ & $\begin{array}{l}\text { AL IBPHE- } \\
\text { NOIDS OF } \\
\text { CROCODILER }\end{array}$ & $\begin{array}{l}\text { ALIBPHE- } \\
\text { NOIDS OF } \\
\text { DTNOBAURA }\end{array}$ \\
\hline $\begin{array}{l}\text { Lateral to basisphenoids and pituitary } \\
\text { fossa } 1 \ldots \ldots \ldots \ldots \ldots \ldots \ldots \ldots \ldots \ldots\end{array}$ & $\mathbf{X}$ & $\mathbf{X}$ & $\mathbf{X}$ & $\mathrm{X}$ \\
\hline Anterior to proöties. $\ldots \ldots \ldots \ldots \ldots \ldots \ldots$ & $\mathbf{x}$ & $\mathbf{X}$ & $\mathrm{X}$ & $\mathrm{x}$ \\
\hline Inferior chiefly to parietals. . . . . . & $\mathrm{X}$ & $\mathbf{X}$ & $\mathbf{X}$ & $\mathbf{X}$ \\
\hline $\begin{array}{l}\text { Posterior to presphenoids and orbito- } \\
\text { sphenoids } \ldots \ldots \ldots \ldots \ldots \ldots \ldots \ldots \ldots \ldots \ldots\end{array}$ & $\mathbf{X}$ & $\mathrm{x}$ & $\mathrm{x}$ & $\mathrm{x}$ \\
\hline $\begin{array}{l}\text { Anterior to foramen proöticum (for } V^{3} \text { ).. } \\
\text { External to Gasserian ganglia, or to sepa- }\end{array}$ & $\mathbf{X}$ & $\mathrm{X}$ & $\mathrm{X}$ & $\mathbf{X}$ \\
\hline $\begin{array}{l}\text { rate trigeminal roots.................... } \\
\text { Chiefly posterior to exits for nerves, II, }\end{array}$ & $\mathbf{X}$ & $\mathrm{x}$ & - & $?$ \\
\hline 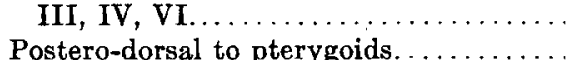 & $\begin{array}{l}\mathrm{X} \\
\mathrm{Y}\end{array}$ & $\mathbf{x}$ & $\mathbf{X}$ & $\mathrm{X}$ \\
\hline $\begin{array}{l}\text { Postero-dorsal to pterygoids............. } \\
\text { Inferior wings laterally embracing basi- } \\
\text { sphenoid } \ldots \ldots \ldots \ldots \ldots \ldots \ldots \ldots \ldots\end{array}$ & $\mathbf{X}$ & $\mathrm{X}$ & $\mathbf{X}$ & $X$ \\
\hline $\begin{array}{l}\text { Inferior wings external to canals for ca- } \\
\text { rotids } \ldots \ldots \ldots \ldots\end{array}$ & $\mathbf{X}$ & $\mathbf{X}$ & $\mathbf{X}$ & $\mathrm{X}$ \\
\hline
\end{tabular}

${ }^{1} \mathrm{X}$ denotes definitely known agreement; $\mathrm{x}$ denotes probable agreement. - denotes disagreement. 


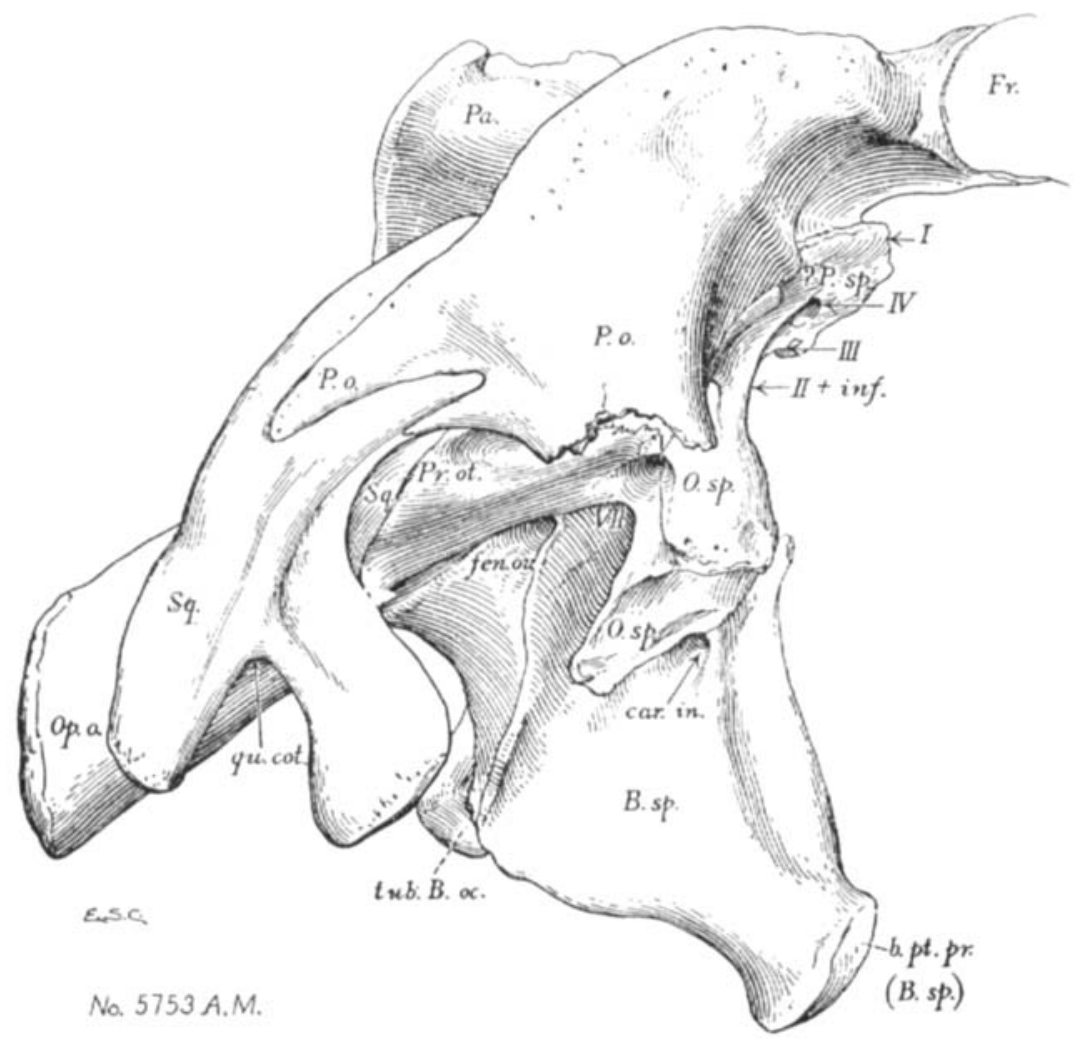

Fig. 8 Brain case of a theropod dinosaur Allosaurus agilis. (Osborn, Mem. Am. Mus. Nat. Hist., n.s., vol. 1, pt.i., text fig. 10, p. 17.) Right side seen obliquely from above. Determination of foramina by the present writer with the kind assistance of Dr. F. von Huene.

The alisphenold (marked $O . s p$.) is seen to be anterlor to the prootic and prootic foramen (V), external to the carotid canal (car. in.) and chiefly posterior to the openings for nerves II, III, IV. The lateral wing marked $P$ P.sp. may represent the orbitosphenoid.

In the Dinosaurs (figs. 8-10) the orbitosphenoids are probably represented by the lateral wings of the elements called by Dr. von Huene 'presphenoids.' These lateral wings are behind the ethmoids, below the frontals and lateral to the median presphenoid, they are also in front of the openings for nerves II, III, IV. The chief differences then between the true orbitosphenoid wings in Dinosaurs and the orbitosphenoids of mammals is that the latter ossify separately from the median presphenoid whereas 


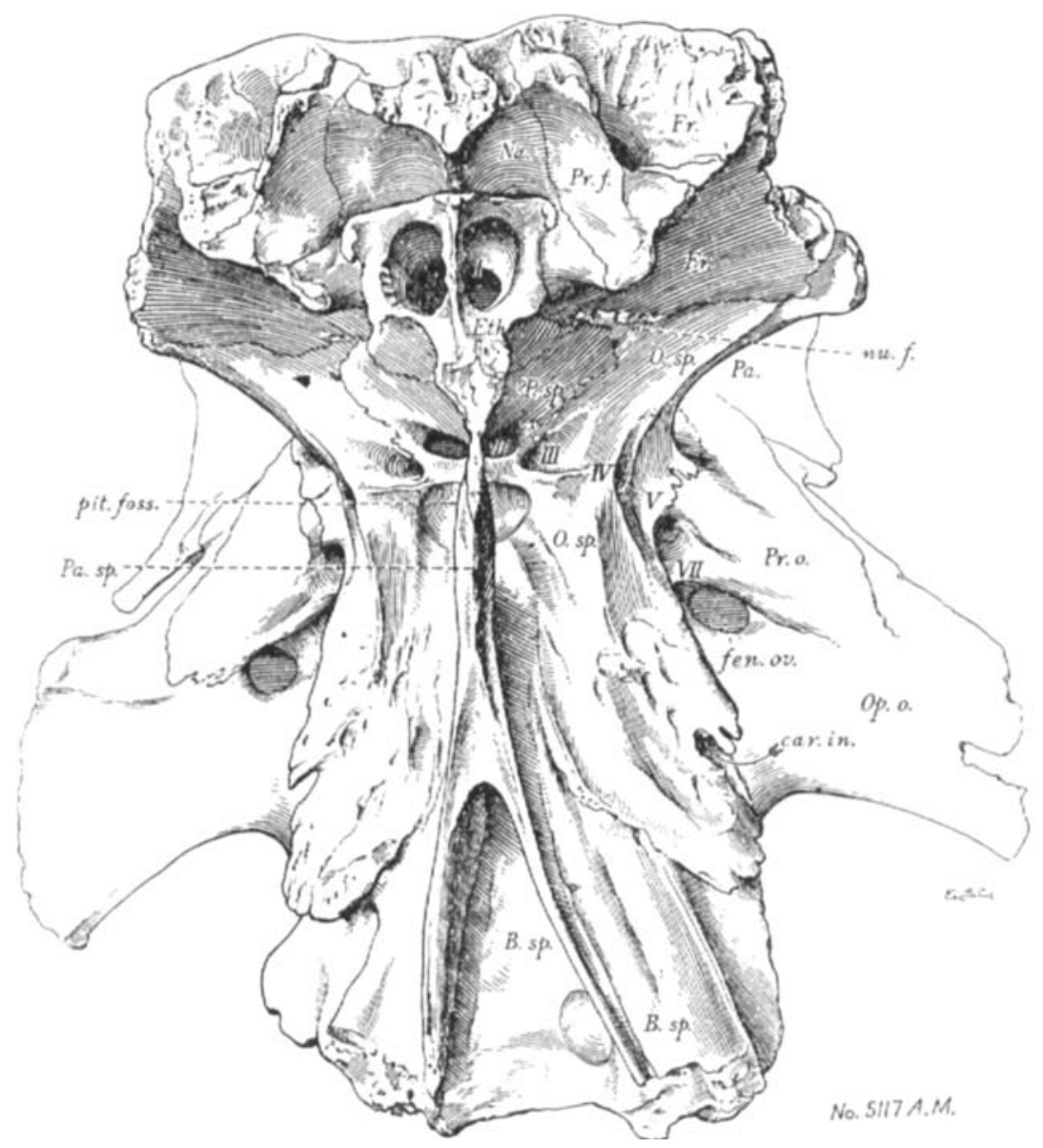

Fig. 9 Brain case of a theropod dinosaur, Tyrannosaurus rex (Osborn, Mem. Am. Mus. Nat. Hist., n.s., vol. i, pt.i., text fig. 8, p. 15). Full front view. Determination of foramina by Mr. Barnum Brown and by the present writer with the kind assistance of Dr. F. von Huene.

The alisphenoid (marked O.sp.) lies behind the foramen for nerves II, III, in front of the prootic foramen (V) and carotid canal. The lateral wing marked $P$ P.sp. may represent the true orbitosphenold, which is continuous below with the presphenoid.

in crocodiles and Dinosaurs they are continuous with the presphenoid.

There can be little doubt then, that the mammalian alisphenoids have been derived from 'alisphenoids' of the type repre- 
sented in the Cynodonts and that these in turn are homologous with the alisphenoids of crocodiles and Dinosaurs. Whence do these alisphenoids of reptiles and mammals arise? Were they derived through the transformation of basipterygoid processes such as are represented in the lizard (Gaupp)? Or were they derived through the transformation of the elements called epipterygoids in Sphenodon (Broom '09)?

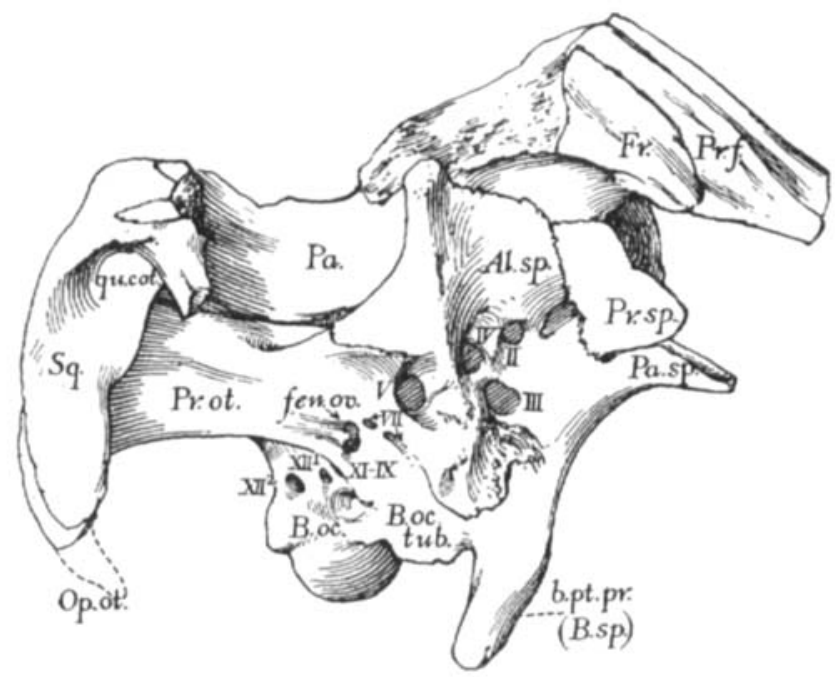

Fig. 10 Brain case of a predentate dinosaur Saurolophus osborni (Barnum Brown, Bull. Am. Mus. Nat. Hist., vol. 31, 1912, p. 134, text-fig. 3).

The alisphenold ( $A l . s p$.) articulates with the prootic; it lies in front of the prootic foramen (V) and chlefly behind the foramen for nerves II, III, IV. Pr.sp., orbito-sphenoid.

In the palatal aspect (fig. 11) of the skull of Gomphognathus (Broom '11, pp. 921-922) the pair of alisphenoids are seen to form a part of the pterygoquadrate series, in so far as they lie between the pterygoids and the quadrates. Likewise in embryo mammals the cartilaginous alae temporalis are interpreted by Broom ('09) as remnants of the cartilaginous pterygoquadrate bar of reptiles.

Broom's 'alisphenoid-epipterygoid' hypothesis is greatly strengthened by the evidence offered both in the chondrocranium 


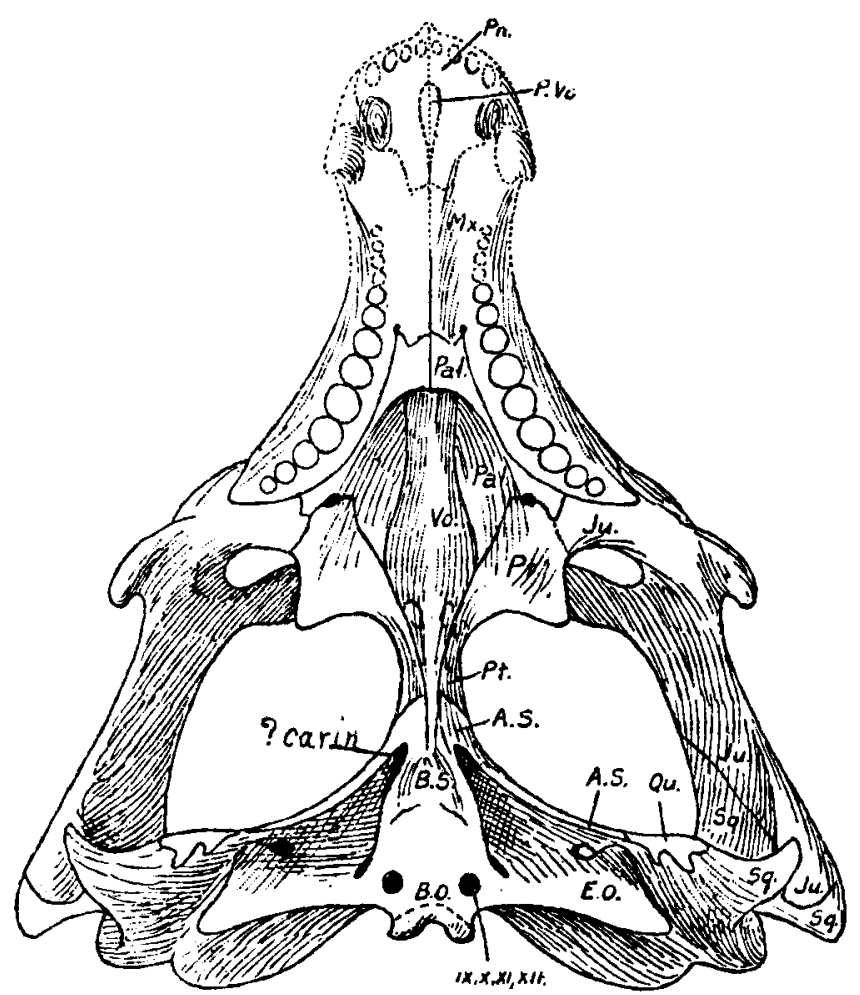

Fig. 11 Under view of skull of Gomphognathus minor. (Broom P.Z.S., 1911. p. 911, text-fig. 177)

The inferior branch of the alisphenoid covers the region of the basipterygoid processes of the basisphenoid. It is external to the supposed carotid canal and is continuous with the pterygoid [Watson].

and in the adult skull of Sphenodon (fig. 12). There the bones usually called epipterygoids have close topographic similarities to the alisphenoids of mammals, Cynodonts, crocodiles and Dinosaurs: viz., they are lateral to the basisphenoid and pituitary fossa, anterior to the proötics, inferior to the parietals, anterior to the proötic foramen (for the trigeminus), and fill the gap between the true orbitosphenoid and the proötics. They differ from the alisphenoid of crocodiles and Dinosaurs in retaining their ancient connection below with the pterygoids (as do also the 'epipterygoids' of the Permian Pelycosaurs, as well as the alisphenoids of Cynodonts). Their cartilage fundaments (fig. 13) 

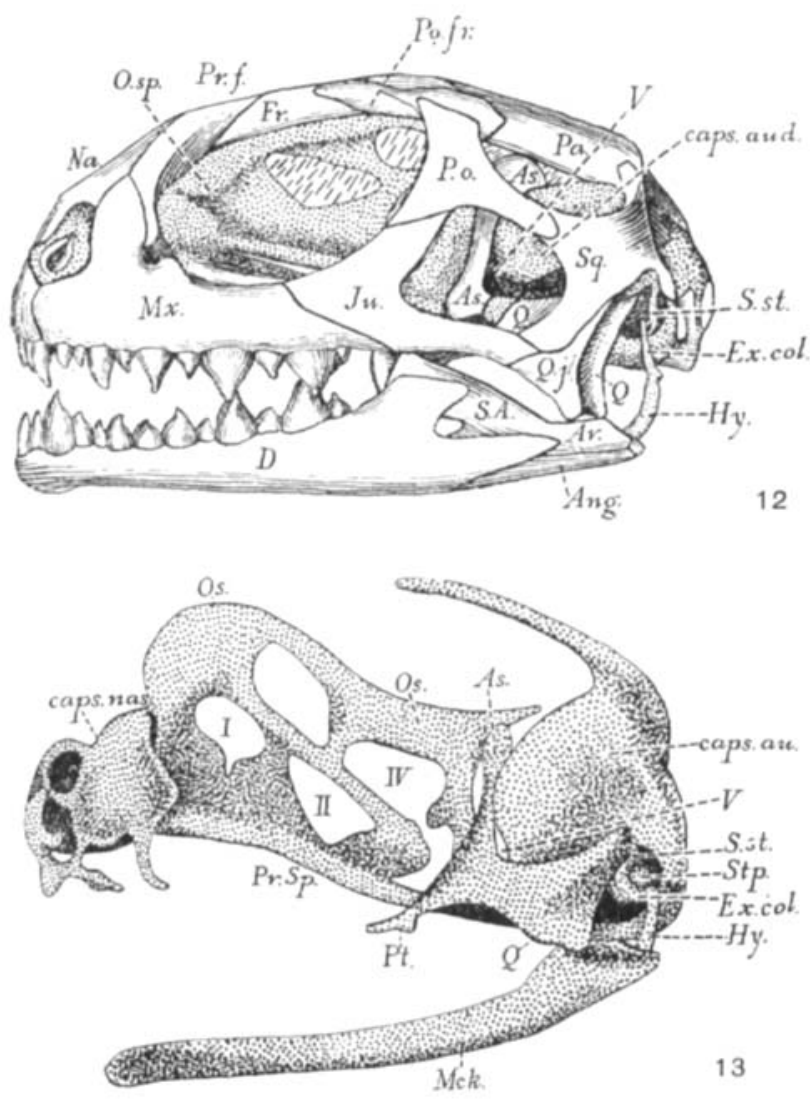

Fig. 12 Developing skull of Sphenodon punctatus. (Howes and Swinnerton, Trans. Zool. Soc., vol. 16. p. iv., fig. 4. Lettering modified.)

The alisphenold (epipterygoid) has essentially the same topographic relations to the prootic (caps. aud.), prootic foramen (V) and parietal ( $P$ a.) as the allsphenold of Crocodiles, Dinosaurs, Cynodonts snd mammals.

Fig. 13 Developing chondrocranium of Sphenodon punctatus. (Howes and Swinnerton, Trans. Zool. Soc., vol. 16, pl. III, fig. 8. Lettering modified.)

From the pterygoquadrate cartilage springs a dorsal branch, the fundament of the eplpterygoid, or alisphenoid. Its topographic relations with the auditory capsule and with the true orbitosphenold are the same as those of the alisohenold of Crocodiles and Dinosaurs.

(Howes and Swinnerton '01, pl. 3, fig. 4) on either side of the skull are vertical rods, which are dorsal processes of the pterygoquadrate cartilage; these vertical rods lie quite outside and below the trigeminal roots. The bases of these epipterygoid rods fuse 
(fig. 14) with the basipterygoid processes of the basisphenoid. If, in the Cynodonts, the cartilage fundaments (alae temporalis) of the alisphenoids (epipterygoids) had fused below with the basipterygoid processes, then, like the basipterygoid processes of lizards and like the alae temporalis of mammals, they would have been below the trigeminal roots and external to the openings for the carotids.

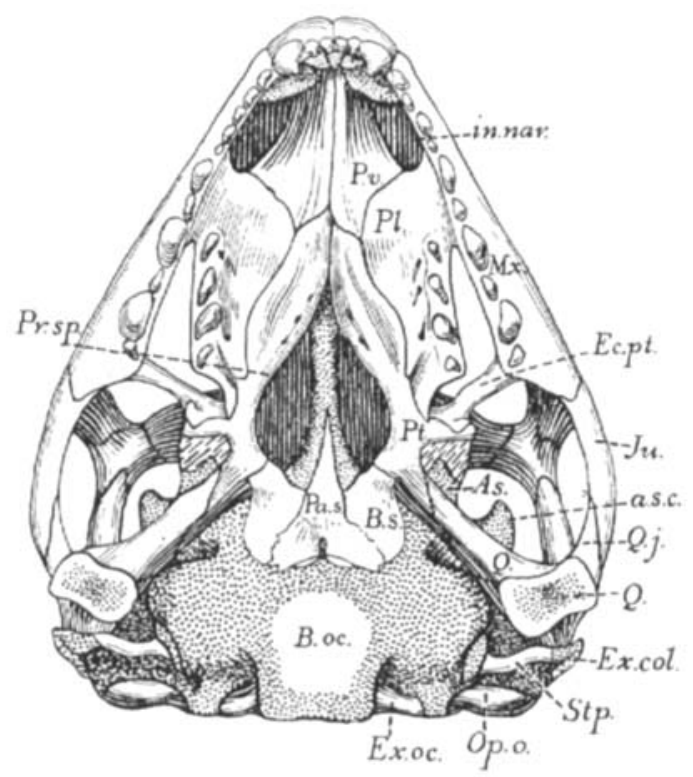

Fig. 14 Under surface of developing skull of Sphenodon punctatus. (Howes and Swinnerton, Trans. Zool. Soc. vol. 16, pl. iv, fig. 16. Lettering modified.)

The cartilage fundament of the alisphenoid $(A, s$ ) is continuous with the basipterygold process, below the postero-external branch of the pterygold. This fact is shown in several of the stages figured by Howes and Swinnerton as well as In two wax models in the American Museum of Natural History which were made by $\mathrm{Dr}$. Dahlgren from serial sections of Sphenodon embryos.

In brief it is not difficult to conceive that all the parallel relations noted by Gaupp between the alae temporalis of mammals and the basipterygoid processes of lizards are due, first to the derivation of mammals from Cynodont-like reptiles retaining certain primitive characters in common with the lizards, and secondly to the fusion of the cartilage fundaments of the pterygoquadrate bars to the basipterygoid processes of the basisphenoid. 
REPTILIAN IJOWER JAW

The nomenclatural history of certain bones of the reptilian lower jaw (fig. 15) has been very intricate and confusing. It is desirable - though hardly to be expected-that stability be gained by a speedy adoption of the following names, which have been selected with great learning and discretion by Gaupp ('11, pp. 124-128) and which in large part have long been used in Germany.

Articulare Cuvier: preformed in cartilage as the articular region of Meckel's cartilage. Remaining unossified in recent Amphibia.

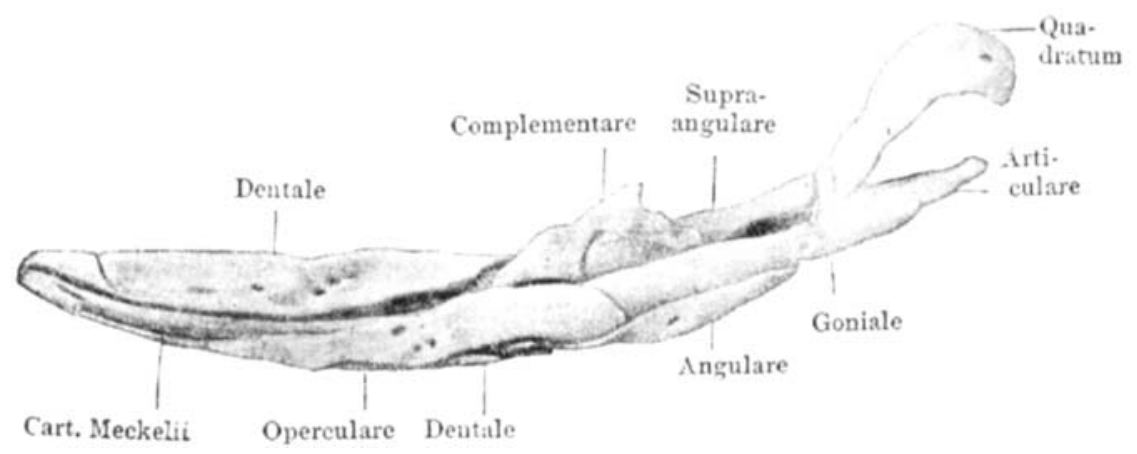

Fig. 15 Model of the lower jaw and quadrate of an embryo Lacerta agilis, medial aspect. (Gaupp, Anat. Anz. Bd. 39, 1911, p. 105, fig. 7.)

Goniale Gaupp (dermarticular Kingsley, postoperculár Gaupp, prearticular Williston): the dermal medial extension of the articular, bordering below the entrance to the 'primordial canal' for Meckel's cartilage; occupying the medial posterior part of the jaw. Present in lizards, snakes, turtles; very large in Amphibia, where it is usually called the angular.

Angulare Cuvier: on the lower border of the jaw, lying between the dentary and the articular, articulating anteriorly with the splenial (operculare). Absent or reduced in recent Amphibia.

Supraangulare Cuvier: (supraangular) on the upper posterior border of the jaw, chiefly on the outer side, above the angulare and goniale. Absent in recent Amphibia.

Dentale Cuvier (dentary Owen): the main antero-external bone of the jaw, bearing the principal row of teeth. In recent Amphibia of ten extending backward to the posterior end of the jaw. 
Operculare Cuvier (splenial Owen): on the inner side of the jaw, opposite the dentary, articulating posteriorly with complementare (coronoid) goniale and angulare. Absent in most Cryptodira and certain other Chelonia: tooth-bearing in certain recent Amphibia. Wrongly named presplenial by Baur in lizards and crocodiles.

Complementare Cuvier (coronoid Owen): lying chiefly on the inner side, between the supraangular and operculare (splenial). Not present in recent Amphibia.

These elements in recent reptiles and Amphibia are very clearly illustrated in the fine series of figures published by Gaupp ${ }^{4}$ representing embryonic and adult conditions.

The critical element for the understanding of the lower jaw of recent reptiles and amphibians is the goniale. This element was recognized by Baur ('95) in the lizard as a 'dermogenous' process of the articular, but he greatly confused the subject by calling the same element in the turtles the 'angular,' by applying to the true or Cuvierian angular the name 'splenial' and by renaming the true splenial 'presplenial.' This strange blunder was set right at last by Williston ('03), Kingsley ('05) and Gaupp. The recognition of the goniale as an element distinct both from the articular and the angular is of great importance, not only in clearing up the morphological relations of these elements in amphibians and reptiles, but also in bringing additional evidence for 'Reichert's theory' of the origin of the mammalian auditory ossicles (see p. 23).

\section{MAMMALIAN LOWER JAW}

From the side of 'neontology' (embryology plus comparative anatomy) the manifold evidence bearing on the origin and morphological relationships of the mammalian lower jaw has been ably arranged by Gaupp (1911, III) in favor of the following conclusions:

1. The mammalian mandible is the homologue solely of the reptilian dentary bone. The ascending ramus including the coro-

41911 , pp. 104-117, figs. 5-16; pp. 437-455, figs. 1-23. 
noid process and mandibular condyle is in all probability homologous with the 'ascending process' of the reptilian dentary. This ascending ramus was originally a process for the insertion of muscles. It became differentiated into two parts, an anterodorsal branch (coronoid) for the temporal muscle and a posteroinferior branch (condylar process) for the external pterygoid muscle.

2. The joint between the lower jaw and the skull in mammals is solely a squamoso-dentary joint which arose in front of the old quadrato-articular joint and in which neither of the old elements (quadrate, articular) participate. In contrast with most

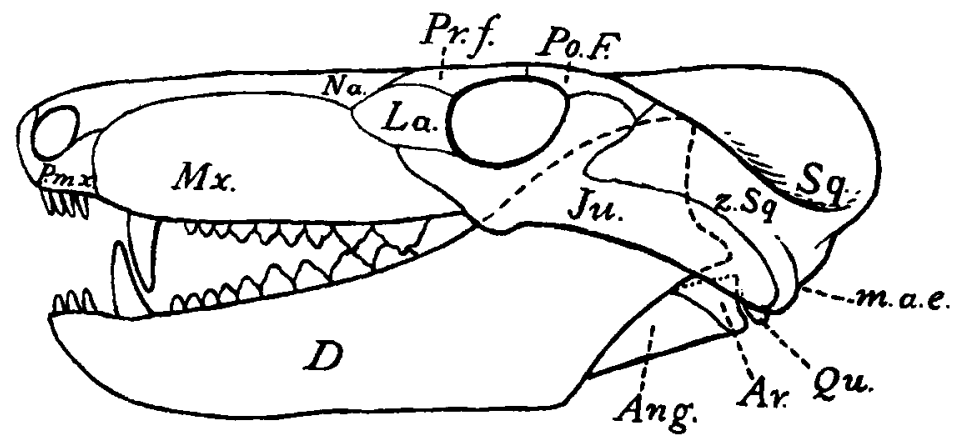

Fig. 16 Scheme showing approximate relations of lower jaw to skull in Cynognathus.

m.a.e. auditory groove.

other joints, the squamoso-dentary joint is thus a secondary attachment of two elements which formerly had no connection. This is also indicated in the ontogeny (see paragraph 6 below).

3 . The quadrate and articular elements of the old reptilian jaw articulation no longer function as such in the mammalian skull but have become transformed into accessory auditory ossicles (incus, malleus, see p. 24).

4. Thus the special peculiarity of the mammalian as compared with the reptilian lower jaw is that in the mammals the anterior tooth-bearing element has become completely separated from the posterior half of the jaw and the two halves now subserve two widely different functions (mastication, audition). 
5. The detachment of the anterior or dentary portion of the reptilian jaw from the posterior portion is a process for which analogies are offered among scarid fishes, Mosasaurs and Caprimulgus. According to Gaupp's view (pp. 657-658) this detachment has arisen in connection with a change in the muscular mechanism for the opening of the mouth. In reptiles, the jaw is depressed chiefly by the depressor mandibulae, which is finally lost in mammals. In mammals the jaw is depressed by the muscles of the floor of the mouth cavity, assisted by the external pterygoid muscles. An increase in size and strength of these muscles, which at first merely assisted the depressor mandibulae and which are all inserted in the dentary bone, would lead, thinks Gaupp, to the detachment of the dentary from the bones composing the hinder half of the jaw. The diminution of the depressor mandibulae muscle may, in turn, be ascribed to the reduction of the quadrate and to the transformation of the skull in the auditory region, under the influence of the rapidly enlarging brain.

6. The secondary attachment of the ascending ramus of the dentary to the squamosal again finds its analogue among the scarid fishes, where an ascending process of the dentary bone has formed a joint with the supramaxillary. The first step in this process in the ancestors of the mammals was probably the formation of a simple glandular cavity (Schleimbeutel) between the connective tissue on the lower surface of the squamosal and the connective tissue covering the ascending process of the dentary (see paragraph (1) above) at the place where the external pterygoid muscle was inserted. The meniscus or interarticular disc $(1911$, pp. 659, 626-629) represents a separated portion of the connective tissue covering the condyle (Gaupp, Lubosch), is continuous with the fibers of the external pterygoid muscle and has nothing whatever to do with the quadrate (with which element Broom ('90) had sought to homologize it).

The cartilaginous epiphysis ('accessory cartilage') of the condyle, which is very large in embryonic stages, is not a portion of the primordial chondrocranium, but is purely secondary, like the cartilaginous areas in many other dermal bones (Gaupp '07). 
(Fuchs had tried to show-'09, pp. 237-242-that the cartilaginous epiphysis of the mandible was derived from the articular portion of Meckel's cartilage, and that the meniscus represented the distal portion of the quadrate, a view which may now be regarded as having been thoroughly disproved by Gaupp.)

7. The connection between the ascending ramus of the dentary and the squamosal was at first loose and mobile (Gaupp '11, p. 658). The temporary 'fixation' of the dentary upon the squamosal as a fulcrum was effected by the muscles which were inserted on the dentary, serving as 'active ligaments.' The new joint at first acted only as a force-resolving mechanism (? with reference to the direction and strength of the several components of the muscular pulls), while in higher types such as the Mustelidae, which have acquired a hinge-joint, motion and the direction of pressure are greatly limited.

8. The increase in size and backward growth of the ascending ramus of the dentary and its final contact with the squamosal are to be ascribed to three influences or conditions: $(a)$ the general upward and backward trend of the ascending ramus itself, which would favor further development in the same direction; (b) the progressive diminution of the quadrate, a process which may on other grounds be confidently predicated of the ancestral mammals; $(c)$ the transformation of the skull as a whole in the auditory region (diminution and basal displacement of the auditory capsule due to the broadening of the brain). As a result of these conditions the contact of the squamosal and the dentary took place in front of the old quadrato-articular joint, as is evidenced by the relations of the auriculo-temporal nerve and by the detrahens muscle of monotremes (Gaupp '11, p. 657).

9. The development of the new jaw articulation must have taken place in forms possessing a zygomatic arch such that the hinder half was composed of the squamosal ('11, p. 657).

Those who look scornfully at the theoretical deductions of comparative anatomy as mere flimsy plausibility, unverifiable hypotheses, will doubtless see in Gaupp's conclusions only a confirmation of their sceptical opinions. But those, who by patient study succeed in gaining a fair insight into these complex 
matters, will realize that Gaupp has developed a perfectly consistent body of doctrines, resting upon many independent lines of evidence and offering a highly probable explanation of the two-fold problem of the lower jaw and of the auditory ossicles.

It seems truly remarkable that these elaborate conclusions, developed with practically no aid from palaeontological evidence, should now be found to be entirely consistent with it. 'Neontologists,' as a rule, have been so busy gathering and sifting the intricate facts furnished by recent forms, they have devoted so much energy to the elaborate embryological technique, they have heard so much and so often about the fragmentary nature of palaeontological evidence, that until very recently they have failed to realize the critical importance in the problems under consideration of the Theriodont reptiles of the Permian and Triassic. Palaeontologists, on the other hand, with the passing of Owen, Cope and Baur, have for the most part ceased to contribute to neontological research on the vertebrate skull and with few exceptions, have taken little or no part in discussing the origin of the mammalian lower jaw and auditory ossicles.

The first effective application of palaeontological evidence to the lower jaw problem was made by Dr. R. Broom ('04) who pointed out the marked approach toward mammalian conditions exhibited by the Theriodonts and suggested that the ascending ramus of the dentary grew backward until the condylar region came into contact with the squamosal. The next year Gaupp ('05) without reference to the Theriodonts, suggested the same view, but his explanation of the manner in which the new joint arose was based largely on the conditions in the lizard, and these conditions as elsewhere shown (Gregory '10) are essentially unfavorable to the origin of the mammalian type of articulation. Gaupp ('11, pp. 619-623) now accepts the lower jaw of Cynognathus (fig. 16) as virtually offering the fulfilment of the hypothetical conditions for the jaw of the ancestral mammal. 


\section{MAMMALIAN AUDITORY OSSICLES}

In all the field of vertebrate morphology there is perhaps no more remarkable theory than that associated with the name of Reichert ('37). This theory deals with the origin of the auditory ossicles in stapediferous vertebrates; it holds that these ossicles represent the transformed elements of the visceral arches of fishes and in particular that the quadrate of reptiles is the homologue of the mammalian incus, the articular of the malleus. Even before Reichert, Gaupp tells us ('11, p. 123) the homology of the malleus with the articular had been suggested by J. F. Meckel ('20) and the homology of the incus with the quadrate by C. G. Carus ('18). Like every other great theory, this one had to undergo a long period of opposition and during the preceding century it evoked an extensive literature. The whole subject was carefully reviewed independently by Gaupp ('99) and by Kingsley ('00), and both of these authors strongly supported the Reichert theory.

Since then Gaupp has further strengthened this doctrine in his work on the development of the skull of Echidna ('08) and in several later works ('05, '09, '10, '11). Interest has been added to the subject by the polemical opposition of Fuchs ('09) to Gaupp. Many other workers, such as Bender, Drüner, Lubosch, Kjellberg, Schulman, Toldt, have also made valuable contributions to the subject.

In general the most important evidence for homologizing the quadrate and articular of reptiles with the incus and malleus respectively of mammals lies in the parallel, essentially identical, topographic relations and mode of development of these two sets of elements in the two classes. This parallelism in topographic relations and in development although marked by wide adaptive differences, is so fundamental, so extensive, so complex, that the possibility of these resemblances being accidental or due to convergent evolution seems practically excluded.

To recall only a few points in this complex evidence ${ }^{5}$ the malleus of mammals is developed as the proximal or articular portion

'For a fuller discussion, see Gregory, "The orders of mammals," 1910, pp. 125-143. 
of the primary lower jaw; the developing incus has every appearance of representing the quadrate and has similar relations with reference to the stapes (p. 28), to the chorda tympani nerve (fig. 21), to the squamosal (p. 26), to the inner ear (p. 27) and to the tympanic cavity (p. 25).

To this remarkable series of parallel relations in mammals and reptiles, Gaupp has recently made known an important addition. The malleus of mammals is a composite structure consisting first of a portion preformed in cartilage (comprising the main mass of the bone and the handle, or manubrium) and secondly of a membranous portion forming the anterior process

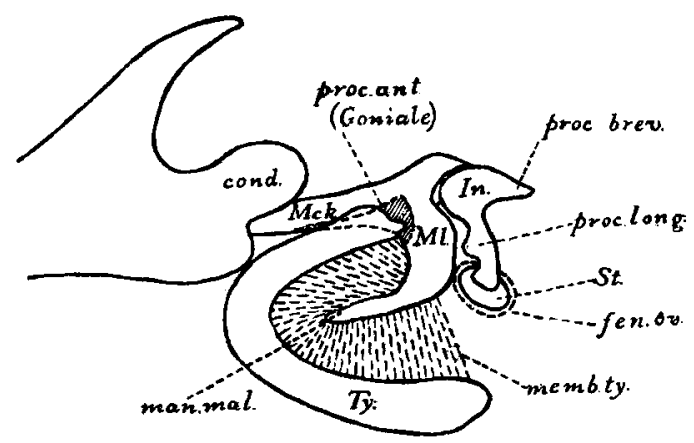

Fig. 17 Developing lower jaw and auditory ossicles of Tatusia hybrida. (Based on Parker, 1885, pl. 5, fig. 3 and pl. 6, fig. 3a.)

The malleus ( $M l$.) is seen to form the articular region of the Meckelian cartilage (Mck.); the dermal bone ensheathing it below, forming the anterior process of the malleus, is homologized by Gaupp with the reptilian goniale. The handle of the malleus (man. mal.) is inserted in the tympanic membrane which is stretcher on the tympanic annulus $(T y$.$) .$

(processus anterior s. Folianus, fig. 17). The cartilaginous portion of the malleus has long been regarded as the articular of reptiles; the dermal portion is therefore regarded by Gaupp as the goniale or prearticular which in the reptiles forms the medial internal extension of the articular. Moreover, both the goniale of reptiles and the anterior process of the malleus of mammals are sometimes pierced by the chorda tympani nerve. For these reasons Gaupp regards the malleus of mammals as the homologue of the gonio-articulare of reptiles.

The evidence favorable to, or consistent with, Reichert's theory offered by the Theriodont reptiles, has until recently remained 
unappreciated. Kingsley ('00), Gadow ('01), Gaupp ('11) and others have held that the Theriodonts, being monimostylic, were definitely excluded from the mammalian ancestry, because, from embryological evidence, the mammals are inferred to have descended from forms with a freely movable quadrate.

The Theriodonts were apparently first considered as favoring the 'quadrate-incus' doctrine in 1909-1910 by the present writer (10) in the following conclusions:

1. In Therocephalians and Cynodonts the progressive enlargement of the ascending ramus of the dentary and the progressive reduction of quadrate, articular and angular were regarded as adaptively correlated processes, tending on the one hand towards the formation of a new squamoso-dentary joint and on the other hand to a decrease in suspensorial functions of the old quadratoarticular joint.

2. From the conditions in Cynognathus, Trirachodon, etc., it seemed plain that the new joint, when established, must have been not far in front of the old joint (fig. 16); that there was more or less slip between the dentary and the angular ('10, p. 137); and that the new and the old joints long functioned together, all these relations being prophesied, as it were, although not attained in known Cynodonts.

3. A certain groove in the base of the skull of Cynognathus (fig. 18) was shown (loc. cit., p. 121) to have identical topographic relations with the auditory groove of mammals; it was, therefore, probably homologous with that structure and hence it was fair to assume that the tympanic cavity and tympanic membrane were closely associated with this groove and consequently lay below the reduced articular and quadrate (loc. cit., p. 122, fig. $113, m b . t y$; p. 141).

4. From these inferred relations of the tympanic cavity and membrane in Cynognathus, and from the fact that in ontogeny the tubo-tympanal cavity grows up around the auditory ossicles which arise outside of it, it was suggested ('10 a, p. 126, fig. $3 \mathrm{~B}$; ' $10 \mathrm{~b}$, p. 600) that phylogenetically this upgrowing of the tubotympanal sac (fig. 19) around the vestigial quadrate and articular may have caused them to share in its vibrations and thus to 


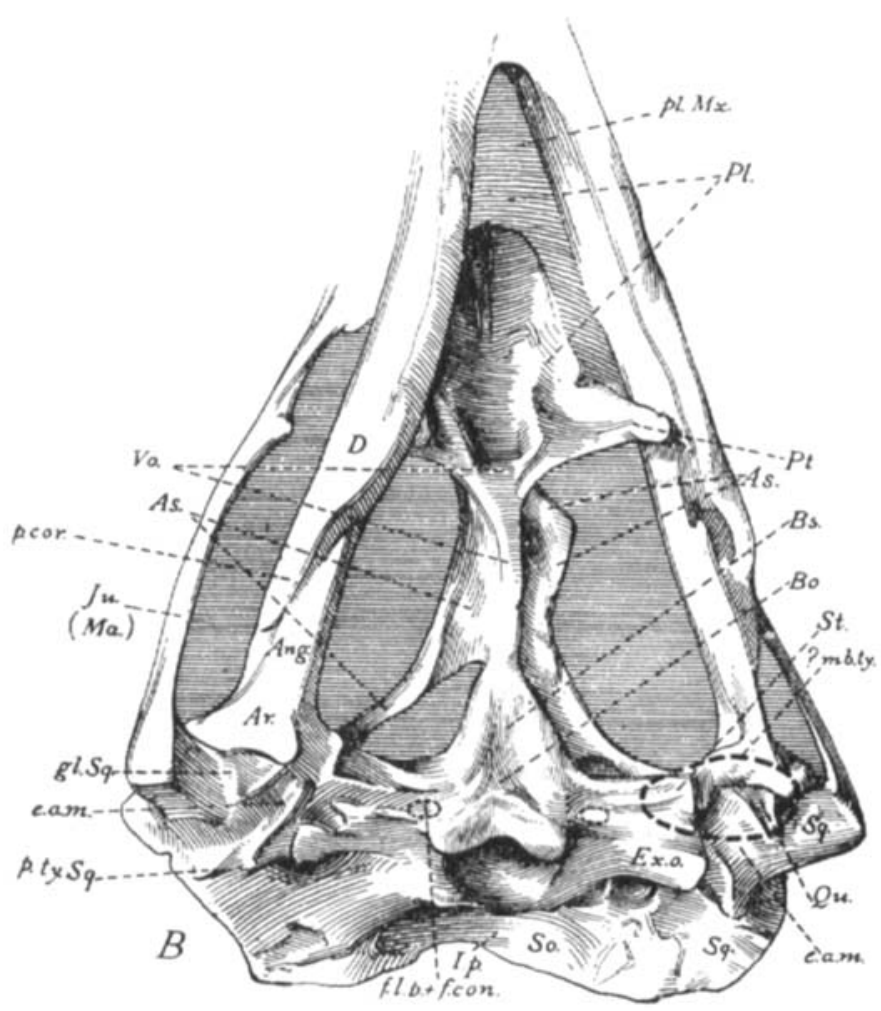

Fig. 18 Base of the skull, with lower jaw attached, of Cynognathus platyceps. Drawn from a cast of the type.

The stapes (St.) is apparently displaced; according to Broom's figure (P.Z.S., 1904, vol. 1, pl. xxxv, fig. I) It should be in contact with the quadrate.

e.a.m., auditory groove; p. $t y . S_{q}$. post-tympanic process of squamosal.

take on an incipient auditory function before their old suspensory function had ceased. It was also suggested that the Weberian apparatus of Siluroid fishes offers a somewhat analogous case: where a tense vibrating sac had literally pressed into its service elements that had subserved originally a totally different function.

5. It was pointed out ('10 a, p. 139) that the minute quadrate of Gomphognathus (fig. 11) resembles the incus of mammals: (a) in being a very small flattened bone located between the 


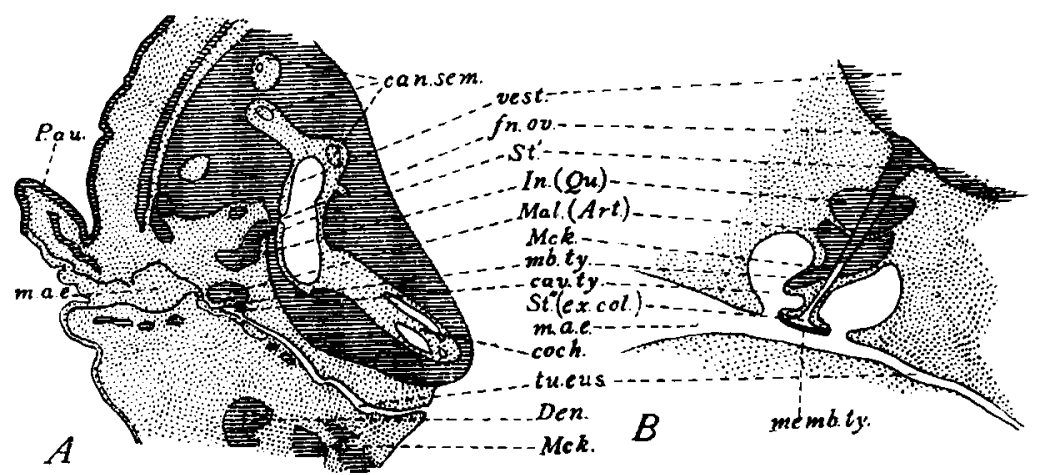

Fig. 19 Relations of the auditory ossicles to the auditory capsule and tubotympanal cavity.

$A$, Cross section of the auditory region in a human embryo of three months. After Minot (lettering modified).

The developing ossicula (St., Mal.) lie above the inciplent tympanic cavity (cav. ty.) which is merely a dilatation of the Eustachian tube (lu.eus.), the supposed homologue of the spiracular gill cleft.

m.a.e., external auditory meatus; mb.ty., tympanic membrane, separating the external auditory meatus from the Eustachian tube.

$B$, Hypothetical scheme of the relations of the stapes $\left(S t^{\prime}\right)$ to the reduced quadrate and articular and to the tubo-tympanal cavity in a pro-mammalian stage.

The quadrate and articular should have been lowered to the region where the stapes joins the extracolumella. The essential idea is the upgrowth of the tubotympanal cavity around the quadrate and irt teular.

proötic and the zygomatic branch of the squamosal; $(b)$ in articulating with the articular (=malleus) by a convex-concave joint.

6. The fact that the quadrate is attached to and partly covered by the squamosal in Cynodonts (fig. 16) considered by all neontologists an insuperable objection to relationship with the mammals was clearly recognized ('10 a, p. 139); but it was hinted that as only the dorsal prolongation of the quadrate was covered by the squamosal, antero-posterior pressure on the lower end of the quadrate would tend to loosen the upper end from its squamosal attachment and thus to transform a monimostylic into a streptostylic condition. ${ }^{6}$

-It also seems reasonable to infer that as the new squamoso-dentary joint was being established the old quadrato-articular joint would be more or less wrenched by the pull of the temporal and other muscles. The matter is further discussed below, p. 36 . 
7. The streptostylic condition of the incus (quadrate) in mammalian embryos was held (' 10 b, p. 600) to be a caenogenetic result of its secondary function as an accessory auditory ossicle. ${ }^{7}$

In the brief time that has elapsed since this application of Reichert's doctrine to the conditions observed in Cynodontia, considerable collateral evidence has become available and certain doubtful questions appear to be nearer to solution. Gaupp's remarkable studies on the lower jaw of vertebrates (see pp. 1821) have practically demonstrated that the mandibular joint of mammals is a secondary joint connecting the squamosal and the dentary; hardly less rigorous is his proof that the malleus represents the gonio-articulare, the incus the quadrate, of reptiles. On the other hand, all of Broom's recent work ('11) has brought cumulative evidence for the view that the Cynodonts are phylogenetically very near to the ancestral mammals.

First in importance among the points discussed but left in doubt in the writer's earlier paper is the homology of the rodlike bone (fig. 18, stp.) in Cynodonts which Broom formerly identified with the mammalian tympanic. It has, however, every appearance of being the bone usually called stapes in Permian reptiles (e. g., Dimetrodon, Case, '07, pl. 19, fig. 2; Labidosaurus, Williston, '10, pl. 2). It also has the appearance of being homologous with the true stapes of Sphenodon. Gaupp ('11, p. 641) thinks it highly probable that the doubted element is a stapes and that, as in Dimetrodon, its outer end was in contact with the quadrate.

Dr. Broom, in a letter to the writer dated July 20, 1911, stated that he had decisive evidence showing that the doubted element is stapes and not tympanic. In Broom's figure ('11, p. 7, pl. 46, fig. 8) of the very primitive Cynodont Bauria this supposed stapes runs out toward the quadrate; its distal end is imperfect, but Broom restores it in contact with the quadrate. The stapes is represented as reaching nearly or quite to the quadrate in Cynognathus (Broom, '04, pp. 490-498, pl. 25) and Oudenodon (Broom), Dimetrodon (Case), Labidosaurus (Williston), as well

\footnotetext{
T In view of the radical change of function some caenogenetic conditions in modern ontogeny are, from all analogies, to be expected.
} 
as in modern snakes, chameleons, tortoises and some urodeles (Kingsbury and Reid) and caecilians (Kingsley). If, as now appears probable, the stapes touched the quadrate in Cynodonts, then it is clear that stapes, quadrate, articular, already formed a connected train of bones (fig. 23). Thus would be met Gadow's objection ('88) that " . . . . the incus cannot be the homologue of the quadrate because of the impossibility of intercalating the quadrate as an incus into the ossicular chain as a link between the stapes (hyomandibula) and lenticulare (sympletic) and the malleus (articulare)." But the quadrate (incus) was not 'intercalated' in the chain; it was there, from the time that the hyomandibular (stapes) became attached to it.

Very obscure and difficult is the complex of questions involving the origin of the handle of the malleus, of the tympanic membrane and tympanic bone (annulus tympanicus), the fate of the reptilian extracolumella and angulare.

In typical reptiles the tympanic membrane is stretched on or near the quadrate, squamosal and articular. Between the inner and outer layers of the tympanic membrane is inserted the extracolumella (fig. 20), which is joined to the true stapes; this extracolumella, like the stapes itself, is believed to be a derivative of the hyoid arch; from the extracolumella springs a dorsal process, the suprastapedial, or intercalare; the ascending hyoid is generally attached either to the extracolumella or to the parotic process of the opisthotic. In mammals the handle of the malleus (manubrium mallei) is inserted into the middle layer of the three layered tympanic membrane; the extracolumella, if present, is not recognized as such and is not connected with the stapes; the hyoid is attached to the periotic.

Kingsley ('00) held that the malleus is a compound element, that the manubrium (fig. 21) in ontogeny arises "distinct from the body of the malleus, that it is at first, like the extracolumella a separate element developing in the tympanic membrane and only later uniting with the rest of the structure." Kingsley therefore concluded that the manubrium mallei had been derived from the extracolumella of the reptilian ossicular chain, a view endorsed also by Fuchs. Hammar and Fuchs have also found 


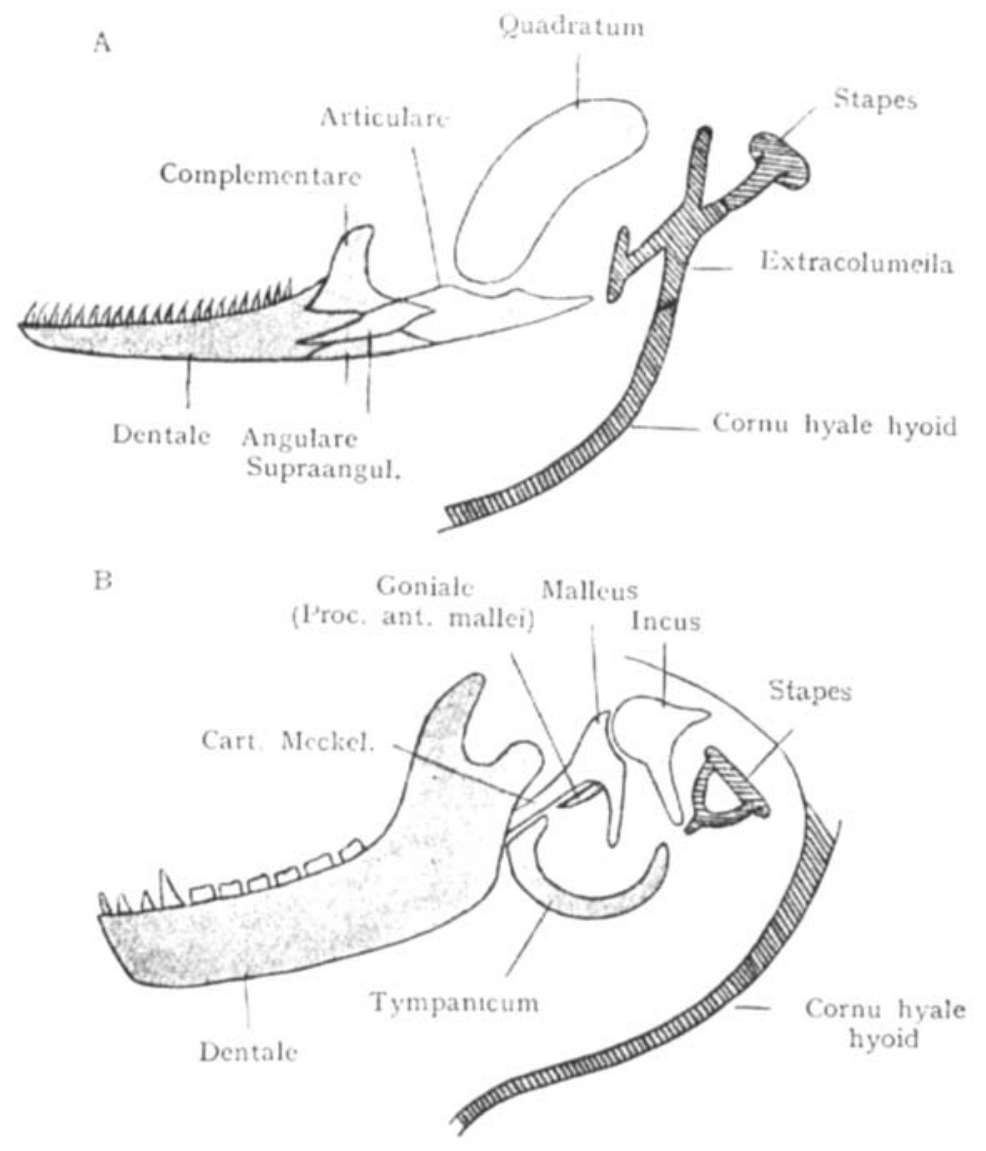

Fig. 20 Schematic representation of the relations of lower jaw and ossicula auditus in $(A)$ saurian embryos and $(B)$ mammal embryos (Gaupp, Verhandl. des VIII. Int. Zool. Kongr. zu Graz, 1910, Fig. 9, p. 231).

Primordial parte of the mandibular arch white, dermal bones of the Meckelian cartilage gray, stapes cross hatched, 'ventrohyal' obliquely hatched. In Sauropsida the upper section of the ventrohyal is represented by the columella, in the mammals the upper end of the ventrohyal is connected with the auditory capsule (Gaupp).

that the manubrium arises independently or at least begins to chondrify peripherally (Gaupp). Gaupp ('09, p. 96;'11, pp. 458459) however, will not admit that the manubrium is the homologue of the extracolumella; he is undecided whether it represents the down turned retroarticular process of the articular or 
a new cartilage (analogous in newness to the ethmoturbinal cartilages), or a derivative of the hyoid.

The reptilian extracolumella and suprastapedial (figs. 12, 20, 22) have been homologized by many authors (including Peters, Cope, Baur, Dollo, Gadow '11, Broom '07) with the mammalian incus and malleus. This is a 'common sense' theory, whose advocates regard the supposed transformation of the quadrate into the incus as an impossibility. The gist of their contention as presented by Gadow, is that the fenestra ovalis of the inner ear and the membrana tympani are fixed points, between which,
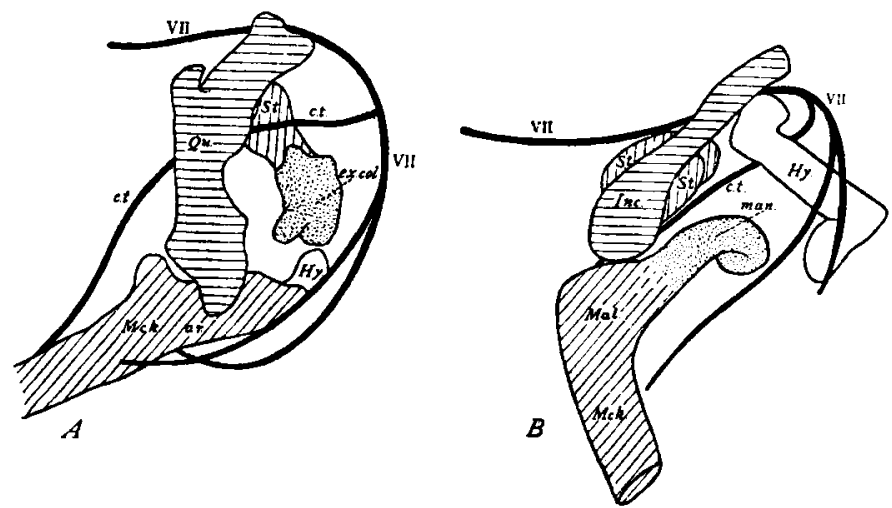

Fig. 21 Schematic representation of Kingsley's view of homologies in ossicula and jaw parts $(A)$ of embryo lizard, $(B)$ of embryo mammal (pig). According to this view the manubrium mallei has been derived from the extracolumella. c.t., chorda tympani.

in the reptile, lies the columella-extracolumella chain and in the mammal the stapes, incus and malleus; that the ossicular chain of Sauropsida is consequently homologous as a whole with that of the mammal and that it is impossible to conceive the intercalation into the mammalian chain of new elements, such as the quadrate and articular. But as shown above (p. 29), the quadrate and articular, according to the best evidence available, were not 'intercalated' into the chain, they were functionally already a part of it.

In support of the hypothesis that the mammalian ossicular chain is homologous with the extracolumella + stapedial rod of 
reptiles Gadow and Broom ('07) took as primitive the conditions revealed in early embryos of the crocodile (fig. 22). Here the extracolumella is continued downward as a strand of cartilage (the 'ceratohyal' of Parker) which is in turn continuous with the Meckelian cartilage behind the articular region. Gadow points out the parallel between this so-called ceratohyal and the malleomeckelian connection of embryo mammals. He says:

The whole string, whether cartilaginous or ligamentous, which connects the downward extracolumellar process with the articulare, is of course ${ }^{8}$ homologous with the continuation of Meckel's cartilage into the malleus of foetal and young mammals.

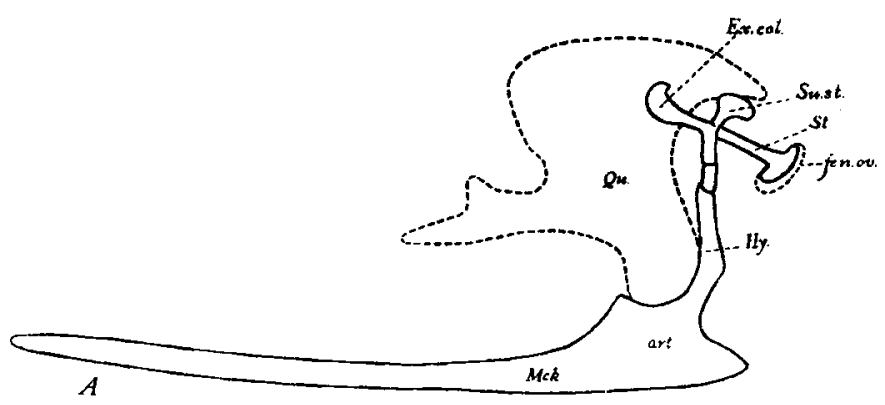

Fig. 22 Lower jaw and auditury ossicles of an embryo Crocodile. After Parker (lettering slightly modified).

The hyold (ceratohyal Parker) is secondarily fused with the posterior part of the articular region of Meckel's cartilage; the hyoid is connected above with the extracolumella and suprastapedial; the stapes (St.) fits Into the fenestra ovalis.

But, apart from the suspicion that conditions in the crocodile are highly specialized (in correlation with the peculiar Eustachian diverticula, etc.), a comparison of the 'ceratohyal' of the crocodile with the hyoid of developing lizards leaves no reason to doubt the homology, which is indeed endorsed by Versluys ('03), after the most thorough researches. Again, in early stages (figs. 12,13 ) of Sphenodon (Howes and Swinnerton '01), the ascending branch of the hyoid is closely appressed to Meckel's cartilage and has every appearance of being homologous with the 'cera-

\footnotetext{
8 Italics mine.
} 
tohyal' of the crocodile. But, if this homology be granted, the very superficial resemblance to the malleo-meckelian connection in mammals is purely accidental and of no bomological significance. Versluys indeed fir.ds ('U3̈, p 177), that this secondary connection by means of the hyoid, is the only way in which the Sauropsid extracolumella is ever connected with the Meckelian cartilage. In brief there can now be little doubt that the malleomeckelian rod of mammals represents solely the first or mandibular visceral arch and has nothing to do with the second arch which is the source of the extracoluuclla and hyoid cornu (cf. Howes and Swinnerton, p. 49). Versluys ('03, p. 177) concluded, in opposition to Peters and others, that the extracolumella and suprastapedial, instead of giving rise to the malleus and incus have practically disappeared in mammals and are only represented by certain transitory embryonic vestiges connecting the stapes and hyoid ('03, Taf. 11, figs. 3, 4.)

With regard to the origin of the mammalian tympanic membrane, it seems likely that at least some of the Cynodonts already approached mammalian conditions. In the remarkably mammallike genus Sesamodon of Broom (fig. 25) the auditory groove (doubtless homologous with that of mammals) indicates essentially mammalian conditions for the tympanic cavity and membrane. On the other hand, in the far more primitive Cynodont Bauria there is little hint of mammalian structures and the tympanic membrane, if differentiated, was probably stretched as in reptiles behind the squamosal and articular.

The stapes of Bauria is supposed to have touched the quadrate; but conceivably it may also have been connected with an extracolumella; just as in embryo lizards the stapes-extracolur mella chain touches the quadrate (Versluys '03, Taf. 8, fig. 8); the hyoid was perhaps still connected with the extracolumella.

The essential feature of a primitive auditory chain is a jointed system of rods, subjected to pressure at opposite ends but kept tense by muscular pull and by direct fastening to adjoining bones. In both mammals and reptiles the outer end of the chain is connected with the tympanic membrane. But is the tympanic membrane homologous in the two classes? 
Great is the need for decisive evidence on this question, but before accenting Gaupp's suggestion ('11, p. 659) that the mammalian and reptilian membranes were differentiated altogether independently, we may put forth the following purely provisional hypothesis embodied in figure 23: that in the most primitive Cynodonts, such as Bauria, there was an extracolumella, resting against a tympanic membrane behind the squamosal, which had been differentiated out of the tissue lying between the endodermal epithelium of the tympañic cavity and the epidermis:

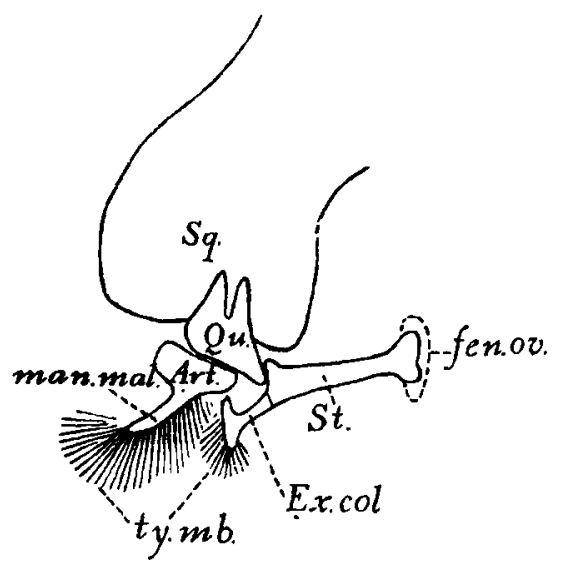

Fig. 23 Hypothetical scheme showing the reptilian extracolumella and the mammalian manubrium mallei ( $=$ ? proc. retro articularis) both functioning at the same time.

that, with the spread of the tympanic cavity (see p. 25) the differentiation of the future tympanic membrane also spread, until it included the stretched skin on the posterior end of the jaw, below the quadrate and articular and above the angular; that concomitantly with the reduction of the quadrate and articular (p. 25) and the detachment of the angular and goniale from the dentary (p. 20), the newly differentiated portion of the tympanic membrane became functionally more active than the old 'reptilian' portion; that, in this way the old membrane together with the extracolumella became vestigial, while the new membrane became altogether free from the dentary, but remained 
fastened both to the angular, which gave rise to the tympanic bone, and to the retroarticular process of the articular, which gave rise to the manubrium of the malleus. With the reduction of the 'reptilian' tympanic membrane the hyoid became separated from the extracolumella (as it does in many lizards) and migrated to a new insertion point on the periotic (but by what path is not clear).

Such an hypothesis or series of hypotheses seems to embody the best available evidence concerning the origin of the manubrium, the origin of the tympanic bone and the fate of the extracolumella. While this matter is still unfortunately in the speculative stage, the evidence tending to show that the tympanic bone has been derived either from the supraangular (van Kampen '05) or preferably from the angular (Gaupp '11, pp. 100, 461) seems of far greater value than the evidence cited by Gadow ${ }^{9}$ to show that the tympanic bone has been derived from the reptilian quadrate.

\section{ORIGIN OF MAMMALS}

From the foregoing pages it will be evident that the most prominent neontologists have looked almost exclusively to Lacerta, Sphenodon, Echidna, Lepus and other recent forms for answers to the intricate problems of skull morphology. Gaupp, in his luminous address ('10) before the Eighth International Zoological Congress, explicitly defends this procedure on the ground that only the recent types afford us an insight into the highly important morphology of the chondrocranium. From various reasons contemporary neontologists have shown a disinclination to extend their morphological studies and conclusions to the extinct types. Although the skull morphology of Cynognathus has been known in its essential facts for many years, it is only recently that Gaupp has discussed the Theriodont lower jaw, which he now recognizes as a fulfilment of his neontological prophecies.

\footnotetext{
9 For a criticism of Gadow's view, see Gregory, The orders of mammals, pp. 128-129.
} 
While recognizing the mammalian tendencies in the Theriodont lower jaw Gaupp still refuses ('11, p. 635) to admit the closeness of the relationship between Theriodonts and mammals:

Damit ist natürlich nicht gesagt, dass die Saüger unmittelbar an Cynognathus-ähnliche Formen anzuschliessen sind; eine solche Vorstellung halte ich bei den mancherlei hohen und einseitigen Spezialisierungen der Theriodonten geradezu für ausgeschlossen. Aus dem Gebiete des Schädels nenne ich hier nur die feste Verkeilung des Quadratums mit den benachbarten Schädelknochen und seine Entfernung von der eigentlichen Ohrgegend durch einen weit nach der Seite vorspringenden Fortsatz (Crista parotica, Proc. paroticus), wie inn auch Rhynchocephalen und Saurier besitzen. Demgegenüber ist der Amboss (das Quadratum) der Saüger beweglich und dicht neben der Ohrkapsel gelagert, und die Crista parotica ist auf die niedrige Crista facialis reduziert,

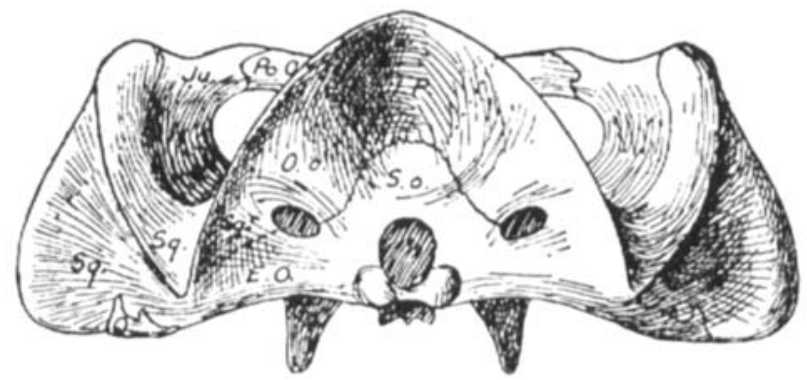

Fig. 24 Occipital view, skull of Gomphagnathus minor. (Broom, P.Z.S. 1911, text-fig. 178 p. 912 ).

unter der der $\mathbf{N}$. facialis verläuft. Indessen kann es uns einstweilen genügen wenn sich überhaupt im Kieferapparat Einrichtungen realisiert finden, die uns einen Hinweis darauf geben, in welcher Weise die Ausbildung der Saügerverhaltnisse möglich war.

Now what are these "manifold high and one sided specializations" of the Theriodonts which exclude them from immediate ancestry of the Mammalia? The first mentioned and traditional objection is the "fast wedging of the quadrate by neighboring skull bones." But we have tried (p. 27) to show that this "fast wedging of the quadrate" is a matter of slight morphological importance, that the quadrate in Gomphognathus (fig. 24) with its projecting lower end, is already in a way to become movable. In the remarkably mammal-like genus Sesamodon 
(fig. 25) the dentition according to Broom ('11, p. 916) indicates "an articulation for the lower jaw which permits of some degree of antero-posterior movement." Does not this antero-posterior movement imply a functionally streptostylic quadrate?

The second point raised by Gaupp to exclude the Theriodontia from mammalian ancestry is the

wide separation of the quadrate from the true auditory region, througn a long lateral parotic process (of the quadrate) as in Rhynchocephalia and lizards, whereas in mammals the movable incus (quadrate) lies close to the auditory capsule and the parotic process is reduced to the low facialis ridge (of the incus), beneath which runs the facial nerve.

But because the Cynognathus quadrate retains certain pr mitive reptilian characters, exhibited also by the quadrate of Rhynchocephalia and lizards, is that a good reason for excluding the Theriodonts from the ancestry of the mammalia? Why not then exclude all reptiles that possess a quadrate, that is to say, all reptiles whatsoever? It is of course entirely consistent with the 'Theriodont theory' that the lower Theriodonts, i. e., the Therocephalians, should have a large and typically reptilian quadrate, while the higher Theriodonts, e. g., Gomphognathus of the Cynodontia, have a reduced quadrate with a reduced parotic process. ${ }^{10}$

What other "high and one-sided specializations" are there, common to all Theriodonts (i.e., Therocephalia + Cynodontia) and not simply generic, which would exclude Theriodontia in their ordinal characters from being the morphological archetypes of the Mammalia? Are they excluded because they retain such primitive reptilian characters as a pineal foramen (lost in Sesamodon) separate prefrontals, postorbitals, 'reptilian' pterygoid and the full complement of upper and lower jaw bones? Are they excluded because some of them, in combination with certain generic specializations, such as the grinding dentition and enlarged squamosals of Gomphognathus, have also acquired many characteristically mammalian characters? What could be more mammalian except the mammals themselves, than Gomphognathus, in the details of its palate, pterygoids, vomer, alisphe-

${ }^{10}$ Cf. figure 11, Broom, 1911. The long parotic process of the 'alisphenoid' is entirely separate, according to Broom, from the parotic process of the quadrate. [But see Postscript below.] 
noids, occipital condyles, interparietal, posttemporal canal (cf. Echidna), etc., than Sesamodon, with its opossum-like zygoma and auditory groove, its infraorbital canal, its nostrils, its lower jaw, its dentition?

The mammalian affinities of the Theriodonts are thrown into even clearer emphasis when we compare other extinct reptiles with the mammals. How wide is the structural gap between mammals, on the one hand, and Pelycosaurs, Cotylosaurs, lizards, Rhynchocephalians, Chelonians on the other. And if we extend our comparisons to the post-cranial skeleton of the Theriodonts ${ }^{11}$ we again find that, after setting aside generic specializations

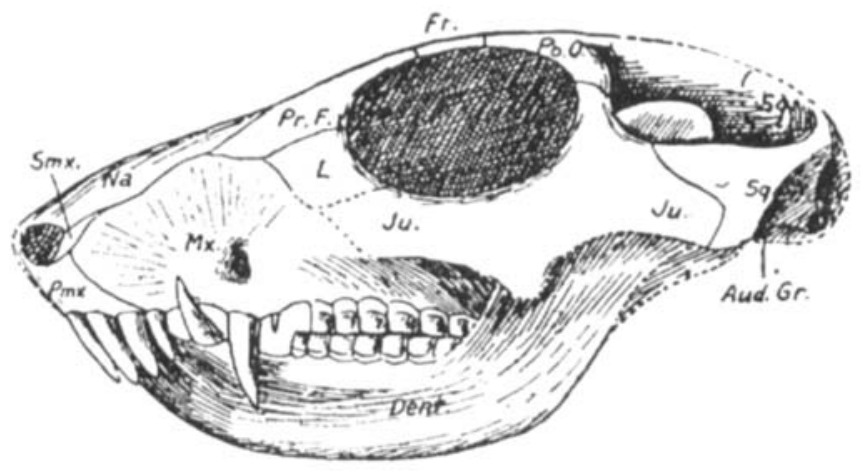

Fig. 25 Skull of Sesamodon browni, the most mammal-like known Cynodont. (Broom P.Z.S. 1911, p. 914, text-fig. 179.)

we have left a great majority of characters favoring the view that the mammals sprang from Cynodonts of some sort. The scapulo-coracoid of Gomphognathus, for example, furnishes the complete $k^{12}{ }^{12}$ to the derivation of the mammalian from the reptilian type; the humerus also is in every respect transitional between the Permian reptile and the mammalian types. Even the true Anomodonts, far removed as they are from direct relationship with the mammals, show an essentially mammalian manus and pes. ${ }^{13}$

\footnotetext{
${ }^{11}$ See the discussion in The orders of mammals, pp. 118-119.

12 Ibid., p. 119.

${ }^{13}$ Ibid., pp. 439-453.
} 
The circle of forms clustering around the true Theriodonts, as Broom has well shown ('07, '10, '11) enable us to pass backward by relatively small steps from the almost mammalian Sesamodon, through Aelurosuchus and Bauria, thence through the Therocephalia to the very lowly order Dromasauria, including small forms with abdominal ribs, a plate-like pelvis and other primitive characters. Thus we are brought within hailing distance of such, in many respects, primitive types as the Pelycosaurs, Poliosaurs, Cotylosaurs, Procolophonia, Rhynchocephalia. This goes far to explain why it is that the mammalian carpus and tarsus, for example, are so clearly foreshadowed in the Permian Varanosaurus (Williston, '11, pls. 8 and 13) and the Pelycosaurs; why the Rhynchocephalia and Squamata have retained certain characters that offer clues for neontological interpretations of the mammalian skull.

In conclusion may be quoted, with entire approbation, the words of Gaupp ('12, pp. 239-240):

Wir haben gefunden, dass, wenn wir die rezenten Formen vom Standpunct der genannten Forderungen aus betrachten, die Amphibien ganz ausscheiden, und dass unter rezenten Reptilienformen die Rhynchocephalen und Saurier die meisten der gestellten Bedingungen erfüllen. Nicht als ob wir die Saüger unmittelbar von Rhynchocephalen oder Sauerien abzuleiten hätten,-das ist selbstverständlich unmöglich,一das aber können wir wohl sagen, dass die beiden genannten Gruppen unter den lebenden Reptilformen in ihrem Schädelbau die meisten Ahnlichkeiten mit den Säugern darbeiten, und dass wir dadurch einen Fingerzeig erhalten, der bei der ferneren Behandlung des Problemes nicht wird ausser acht gelassen werden dürfen. Und darauf kam es mir hier an. Die endliche Lösung phylogenetischer Fragen bleibt der Palaeontologie überlassen, aber einer Palaeontologie, die sich nicht mit souveräner Nichtachtung über alles hinwegsetzt, was Biologie oder Neontologie, Morphologie der rezenten Formen heisst, sondern die Arbeit auch dieser Forschungsrichtung anerkennt und sich dienstbar macht. Nur aus dem Zusammenwirken von Neontologie und Palaeontologie wird ein gesichertes Ergebnis zu erwarten sein.

\section{POSTSCRIPT}

Since the foregoing paper was sent to the editor in June, 1912, several important contributions to the problems discussed above have fallen into my hands. Watson ('11), in his very careful de- 
scription of the skulls of Diademodon and other Cynodonts, states that there is no suture between the epipterygoid, or temporal wing of the alisphenoid, and the pterygoid; that the whole pterygoid plus epipterygoid corresponds and is homologous with the mammalian alisphenoid in all its relations to surrounding elements and to nerve exits. The "pterygoid wings of the alisphenoid" in mammals together with the basal portions of the alisphenoids are therefore homologous with the pterygoids of reptiles. The true mammalian pterygoids, which are slips of bone on the inner side of the pterygo-alisphenoids are homologized by Watson with the ectopterygoids of Cynodonts, as first suggested by Seeley.

These conclusions are entirely consistent with the facts set forth in the preceding pages and offer a very satisfactory explanation of the fate of the ectopterygoids and pterygoids in the Cynodont-like ancestors of the mammals.

Dr. R. Broom ('12) in working out a natural brain cast of Dicynodon finds that the fenestra ovalis of the internal ear is filled by the inner end of the rod-like bone which he formerly called tympanic but which he now recognizes as stapes. The outer end of the stapes abuts against the quadrate. The quadrate therefore corresponds in position with the mammalian incus and Broom accordingly accepts the homologies of the Theriodont quadrate and articular which were suggested by the present writer in 1910, when applying Reichert's theory to the 'Theriodontia.

The writer's application of Reichert's theory to the mammallike reptiles is contested by Dr. Hugo Fuchs ('12). His most important point, the 'fixed' condition of the quadrate in Cynodonts has been dealt with above (pp. 27, 36). The "caudal displacement of the quadrate" in Monotremes has not removed the quadrate very far behind the glenoid region of the squamosal. His views of the homology and relations of the squamosal and of the epiphysial articular cartilage of the mandible have, it seems, already been answered satisfactorily by Gaupp. 


\section{BIBLIOGRAPHY}

Broom, R. 1890 On the fate of the quadrate in mammals. Ann. and Mag. Nat. Hist., November, pp. 409-411.

1904 On the structure of the Theriodont mandible and on its mode of articulation with the skull. Proc. Zool. Soc., vol. 1, pp. 490-498, pl. 25.

1907 On the origin of mammals. Rept. Brit. and So. Afr. Assoc., vol. 3, sep. pp. 1-12.

1909 Observations on the development of the marsupial skull. Proc. Linn. Soc. N. S. Wales, vol. 34, pp. 211-212.

1910 A comparison of the Permian reptiles of North America with those of South Africa. Bull. Am. Mus. Nat. Hist., vol. 28, pp. 204-213. 1911 On the structure of the skull in Cynodont reptiles. Proc. Zool. Soc., December, pp. 893-925.

1912 On the structure of the internal ear and the relations of the basicranial nerves in Dicynodon, and on the homology of the mammalian auditory ossicles. Proc. Zool. Soc., June, pp. 419-425, pl. 56.

Case, E. C. 1907 Revision of the Pelycosauria of North America. Carnegie Institution Publ. 55.

Fuces, H. 1909 Uber Knorpelbildung in Deckknochen, nebst Untersuchungen und Betrachtungen über Gehörknöchelchen, Kiefer und Kiefergelenk des Wirbeltiere. Archiv f. Ant. u. Physiol., Anat. Abt., Suppl.

1912 Über die Beziehungen zwischen den Thermorphen Cope's bezw. den Therapsiden Broom's und den Säugetieren. . . . . Zeitschr. f. Morphol u. Anthopol. Bd. 14, Heft 2, ss. 430-434.

Gadow, H. 1888 On the modifications of the first and second visceral arches, . with special reference to the homologies of the auditory ossicles. Phil. Trans., vol. 179, pp. 451-485, pls. 71-74.

1901 The evolution of the auditory ossicles. Anat. Anz., Bd. 19, pp. $396-411$.

1911 The anatomy of reptiles. Encyclopedia Britannica, 11th Ed., vol. 23, p. 160 .

GaUPP, E. 1898 Ontogenese und Phylogenese des schalleitenden Apparates bei den Wirbeltieren. Ergebnisse der Anat. u. Entwick. (Merkel u. Bonnet.) Bd. 8, (1909) pp. 990-1149.

1902 Über die Ala temporalis der Säugerschädels und die Regio orbitalis einiger anderer Wirbeltiersehädeln. Merkel u. Bonnet's Anatom. Heften. 19 Bd. Heft. 1.

1905 Die Nicht-Homologie des Unterkiefers in der Wirbeltierreihe. Verhandl. d. Anat. Gesellsch., 19 Versamm!. in Genf, pp. 125-138.

1907 Demonstration von Präparaten betreffend Knorpelbildung in Deckknochen. Verhandl. d. Anat. Gesellsch. 21 Versamml. in Würzburg, pp. 251-252.

1908 Zur Entwickelungsgeschichte und vergleichenden Morphologie des Schädels von Echidna aculeata var. typica. Semons Zool. Forsehungsreisen, Bd. 2, Lief. 2, pp. 539-788.

1909 Die Gehörknöchelchen und Unterkiefer-Frage. XVIe Congres international de Médicine, Budapest, $1^{\circ}$ Sect. pp. 81-101. 
Gaupp, E. 1910 Das Lacrimale des Menschen und der Saüger und seine morphologische Bedeutung. Anat. Anz., Bd. 36, pp. 529-555.

1911 Beiträge zur Kenntnis des Unterkiefers der Wirbeltiere. Anat. Anz., Bd. 39. I. Der Processus anterior (Folii) des Hammers der Säuger und das Goniale der Nichtsäuger., pp. 97-135. II. Die Zusammensetzung des Unterkiefers der Quadrupeden, pp. 443-473. III. Das Problem der Entstehung eines 'sekundaren' Kiefergelenkes bei den Säugern, pp. 609-666.

1912 Die Werwandtschaftsbeziehungen der Säuger, vom Standpunkte der Schädelmorphologic aus erörtert. Verhandl. d. VIII. Int. Zool. Kongr. zu Graz vom 15-20 Aug. 1910, pp. 215-240.

Gregory, W. K. 1910 a The orders of mammals. Bull. Am. Mus. Nat. Hist., vol. 27 , pp. 125-143.

$1910 \mathrm{~b}$ Application of the quadrate-incus theory to the conditions in Theridont reptiles and the genetic relations of the latter to the Mammalia: Science, n. s., vol. 31, p. 600 .

Howes, G. B., ANd Swinnerton, H. H. 1901 On the development of the skeleton of the tuatara, Sphenodon punctatus. Trans. Zool. Soc. Lond., vol. 16, pp. 1-86, plates 1 to 6 .

von Huene, F. 1911 Beiträge zur Kenntniss und Beurteilung der Parasuchier. Geol. u. Pal. Abhandl. herausgegeben von E. Koken. n. F., Bd. 10, p. 43.

van Kampen, P. N. 1905 Die Tympanalgegend des Säugetierschädels. Morphol. Jahrbuch, Bd. 34, pp. 321-722.

KingsBory, B. F., AND ReID, H. D. 1909 The columella auris in Amphibia. Jour. Morph., vol. 20, pp. 549-626, 10 plates.

Kingstey, J. S. 1900 The ossicula auditus. Tufts College Studies, Vol. 1, pp. 203-274.

1905 The reptilian lower jaw. Amer. Nat., vol. 39.

Osborn, H. F. 1912 Crania of Tyrannosaurus and Allosaurus, Mem. Am. Mus. Nat. Hist., n. s., vol. 1 , pt. 1.

PARKER, W. K. 1883 On the structure and development of the skull in the Crocodilia. Trans. Zool. Soc., vol. 11, pp. 265-310, plates 62-71. 1873-1885 On the structure and development of the skull in the mammalia. Phil. Trans.. Part I, Sus scrofa, 1873; Part II, Edentata, 1885; Part III, Insectivora, 1885.

REIchert, C. 1837 Ueber die Visceralbogen der Wirbeltiere im allgemeinen und deren Metamorphosen bei den Vögeln und S̈̈ugethieren. Müller's Arch. f. Anat. Physiol. u. Wissensch. Med., pp. 120-122, 3 Taf.

Thrng, F. W. 1906 The squamosal bone in the tetrapodous vertebrata. Proc. Boston Socy. Nat. Hist., vol. 32; also Tufts College Studies, vol. 2.

Versluys, J. 1903 Entwicklung der Columella auris bei den Lacertiliern. Zool. Jahrb., Abt. f. Anat. u. Ontog. (Spengel), Bd. 19.

Watson, O. O. 1911 The skull of Diademodon, with notes on those of some other Cynodonts. Ann. and Mag. Nat. Hist., ser. 8, vol. 8, pp. 293-330.

Wiruiston, S. W. 1903 Some osteological terms. Science, n. s., vol. 28, pp. 829-830.

1910 The skull of Labidosaurus. Am. Jour. Anat., vol. 10.

1911 American Permian vertebrates. Chicago. 